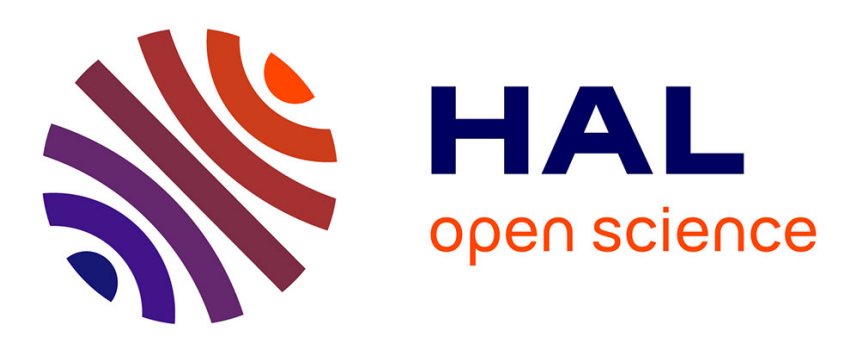

\title{
Characterization of tissue specific differences in cell wall polysaccharides of ripe and overripe pear fruit
}

Marwa Brahem, Catherine M.G.C. Renard, Barbara Gouble, Sylvie Bureau, Carine Le Bourvellec

\section{- To cite this version:}

Marwa Brahem, Catherine M.G.C. Renard, Barbara Gouble, Sylvie Bureau, Carine Le Bourvellec. Characterization of tissue specific differences in cell wall polysaccharides of ripe and overripe pear fruit. Carbohydrate Polymers, 2017, 156, pp.152-164. 10.1016/j.carbpol.2016.09.019 . hal-02624798

\section{HAL Id: hal-02624798 \\ https://hal.inrae.fr/hal-02624798}

Submitted on 26 May 2020

HAL is a multi-disciplinary open access archive for the deposit and dissemination of scientific research documents, whether they are published or not. The documents may come from teaching and research institutions in France or abroad, or from public or private research centers.
L'archive ouverte pluridisciplinaire HAL, est destinée au dépôt et à la diffusion de documents scientifiques de niveau recherche, publiés ou non, émanant des établissements d'enseignement et de recherche français ou étrangers, des laboratoires publics ou privés. 


\title{
Characterization of tissue specific differences in cell wall polysaccharides of ripe and overripe pear fruit
}

\author{
Marwa Brahem, Catherine M.G.C Renard, Barbara Gouble, Sylvie Bureau, \\ Carine Le Bourvellec* \\ UMR408 SQPOV, Sécurité et Qualité des Produits d'Origine Végétale, INRA, Avignon University, F-84000 Avignon, France
}

\begin{abstract}
A B S T R A C T
Cell walls from flesh, parenchyma cells, stone cells and skin were isolated from ripe and overripe Pyrus communis L. cv "De Cloche" using the phenol-buffer method. Pear polysaccharides were solubilized from cell walls by sequential extractions with aqueous solutions of ammonium oxalate, $\mathrm{Na}_{2} \mathrm{CO}_{3}$, and increasing concentration of $\mathrm{NaOH}$, to explore overripening impact. Cell walls were also differentiated using MIR spectral data. Stone cells contained high levels of xylose and lignin while parenchyma cells had high levels of glucose, uronic acids and arabinose. Sequential extractions revealed that pear pectins had highly branched rhamnogalacturonans and were extremely methylated. Xylans were the main hemicelluloseespecially for stone cells. Cellulose represented about half of all cell walls. This heterogeneous composition of pear affected differently cell wall evolutions and properties. Thus, overripening involved a decrease in arabinose and a loss of pectic side chains mostly from parenchyma cells. Changes in hemicellulose and cellulose were minor.
\end{abstract}

Pyrus communis $\mathrm{L}$.

Pectin

Hemicellulose

Cellulose

Sequential extraction

\section{Introduction}

Cell walls are important features of plant cells and are implicated in evolution of fruit firmness and texture during ripening. Cell walls have among others a major impact on fruit juice composition by their interactions with condensed tannins also known as proanthocyanidins (Le Bourvellec, Le Quere, \& Renard, 2007). Pear juice but not pear fruit phenolic composition depends on fruit maturity at pressing. Previous studies showed that pear juice with very high procyanidin concentrations is obtained from ripe fruit whereas juice obtained from overripe fruit is almost devoid of procyanidins although they are strongly present in the fruit (Guyot, Marnet, Le Bourvellec, \& Drilleau, 2002). The availability of procyanidins in the juice was limited by the formation of non-covalent adducts with cell walls (Guyot, Marnet, Sanoner, \& Drilleau, 2003; Le Bourvellec et al., 2007; Smith, McRae, \& Bindon, 2015), hence

Abbreviations: FAD, Factorial Discriminant Analysis; MIR, Mid Infrared; SEM, Scanning Electron Microscopy; CWM, Cell Wall Materials; FL, cell walls isolated from the whole flesh; PC, cell walls isolated from parenchyma cells; ST, cell walls isolated from stone cells; SK, cell walls isolated from skin.

* Corresponding author. INRA, UMR408 SQPOV, Sécurité et Qualité des Produits d'Origine Végétale, 228 route de l'Aérodrome, CS 40509, F-84914 Avignon cedex 9, France.

E-mail addresses: marwabrahem90@yahoo.fr (M. Brahem), catherine.renard@inra.fr (C.M.G.C Renard), barbara.gouble@inra.fr (B. Gouble), sylvie.bureau@inra.fr (S. Bureau), carine.le-bourvellec@inra.fr (C. Le Bourvellec). modifications of pear cell wall affinity for procyanidins might also explain this difference between ripe and overripe stage.

In most species of the Rosaceae family fruit flesh is very homogeneous and is predominantly composed of parenchyma cells. However, in pears, Pyrus communis L., the cortical tissue contains also stone cells. The later, also known as sclereids, give a gritty texture when pears are eaten or processed into juice, puree and jam. Stone cells are a type of sclerenchyma cell formed by the secondary thickening of cell walls, followed by the deposition of lignin on the primary walls of parenchyma cells. Occurrence of stone cells has also been reported in other fruits such as guava (Marcelin, Williams, \& Brillouet, 1993). The formation of stone cells is influenced by several factors such as cultural practices, post-harvest handling but the most important factor is the genetic variability (Cai et al., 2010; Yan et al., 2014), from almost imperceptible in some cultivars to very gritty texture in perry pears. Their formation includes lignification, which usually occurs during plant growth, when cell growth is completed or cells undergo secondary growth. It plays crucial role in plant defense against biotic and abiotic stress (Vance, Kirk, \& Sherwood, 1980). Sclereids contain abundant cellulose (Cai et al., 2010) and a high level of glucose and xylose (Martin-Cabrejas, Waldron, Selvendran, Parker, \& Moates, 1994). Data which already exists on pear cell walls take into account only the whole flesh without separation between stone cells and parenchyma cells (Ahmed \& Labavitch, 1980; Almeida, Gomes, \& Pintado, 2009; Hiwasa et al., 2004; Jermyn \& Isherwood, 1956; Murayama, Katsumata, Endou, 
Version définitive du manuscrit publiée dans / Final version of the manuscript published in :

Carbohydrates Polymers (2017), Vol. 156, p. 152-164, DOI: 10.1016/j.carbpol.2016.09.019

\section{Journal homepage : www.elsevier.com/locate/carbpol}

Fukushima, \& Sakurai, 2006; Raffo, Ponce, Sozzi, Vicente, \& Stortz, 2011; Renard, 2005b; Yamaki, Machida, \& Kakiuchi, 1979).

In general, cell wall modifications during fruit ripening involve hydrolysis of neutral sugars from pectin side chains, depolymerization and increased solubilization of pectins and hemicelluloses (Brummell, 2006). Minor changes can occur in cellulosic material (Houben, Jolie, Fraeye, Van Loey, \& Hendrickx, 2011). During ripening of pears, the most commonly reported modifications taking into account only the whole flesh indicate a loss of arabinose (Ahmed \& Labavitch, 1980; Jermyn \& Isherwood, 1956), or arabinose and uronic acid (Martin-Cabrejas et al., 1994a,b; Yamaki et al., 1979). Hiwasa et al. (2004) suggested that cell wall degradation is correlated with a decrease in firmness during ripening and the modification of both pectins and hemicelluloses are essential for the development of melting texture in different species of pears. Although in lignified cell wall of stone cells the ultrastructure does not change during fruit maturation, in overripe fruit the parenchyma cell walls became extremely thin and fragile (BenArie, Kislev, \& Frenkel, 1979). Therefore, our hypothesis is that pear cell walls from parenchyma and sclereids have different compositions and evolve differently from ripe to overripe stage. These differences further may influence the affinity of cell wall for procyanidin and their extraction to juice. This cell wall-procyanidin interaction is background information and not tested here. However, little data was available on pear cell wall composition taking into account sclereid cells and parenchyma cells separately. The aim of this study was to characterize the composition and ultrastructure of pear cell walls differentiating skin and flesh tissue, and in the flesh differentiating parenchyma and stone cells. We report also the changes that occur in the various types of cell walls (whole flesh, parenchyma cells, stone cells and skin) to better understand the evolution of each tissue for ripe and overripe pears. This work provides the baseline data for further studies examining the impact of cell walls-procyanidins interactions in pear.

\section{Materials and methods}

\subsection{Standards and chemicals}

Phenol, methanol and ammonium oxalate were from Merck (Darmstadt, Germany). Sodium carbonate, sodium hydroxide, sodium borohydride $\left(\mathrm{NaBH}_{4}\right)$, sodium acetate, $\mathrm{N}$-methylimidazole, acetic anhydride, formic acid, lignin alkali, glucose, galacturonic acid, toluene- $\alpha$-thiol, methanol-d3, (+) catechin, (-) epicatechin and inositol were from Sigma-Aldrich (Deisenhofen, Germany). Sugars (arabinose, fucose, galactose, xylose, mannose and rhamnose) were from Fluka (Buchs, Switzerland). Dextrans were from Pharmacia BioProcess Technology (Uppsala, Sweden). Acetonitrile of HPLC grade was obtained from VWR International (Radnor, USA). Ethanol and acetone were from Fisher Scientific (Strasbourg, France).

\subsection{Plant material}

Pyrus communis L. cv "De Cloche", a special cultivar used to make perry, was used. Perry manufacturers produce pear juice from fruits in advanced stage of maturity to decrease the astringency and to increase colloidal stability during storage of perry. Two maturity stages were chosen from this empirical assessment, "Ripe" corresponding to pears at harvest, i.e. December 03, 2013 in the orchard of Mr. Aubry (Clécy, France), and "Overripe" (described as "soft under the fingers") corresponding to fruits stored for 5 days at $10^{\circ} \mathrm{C}$ and then for 3 days at room temperature. Ripe and overripe pears were peeled and cored manually. Formic acid solution $(10 \mathrm{~mL} / \mathrm{L})$ was sprayed on the fresh material during these later operations to avoid phenolic oxidation. Skin and flesh were separately frozen $\left(-20^{\circ} \mathrm{C}\right)$ until used.

\subsection{Firmness}

Firmness was measured at harvest for ripe pears and after 8 days of storage corresponding to the 5 days at $10^{\circ} \mathrm{C}$ and 3 days at room temperature for overripe pears using a multi purpose texturometer (Texture analyser TAplus: Ametek, Lloyd Instruments Ltd., Fareham, UK). Fruit without skin was placed on a stationary steel plate and penetrated to depth of $3 \mathrm{~mm}$ with a $2 \mathrm{~mm}$ diameter probe at a speed of $100 \mathrm{~mm} / \mathrm{min}$. A batch of five fruits was constituted for each maturity stage. Four determinations were conducted in the four sides for each fruit. The work to limit, defined as the energy of penetration into flesh up to $3 \mathrm{~mm}$ depth, was registered during the test and results were expressed in Joules (J) (Choi, Choi, Hong, Kim, \& Lee, 2007; Sirisomboon, Tanaka, Fujita, \& Kojima, 2000).

\subsection{Cell wall isolation and extraction}

Cell Wall Materials (CWM) were prepared by the phenol buffer method according to a method adapted from Renard (2005b) for each maturity and from fruit differentiating skin and flesh tissue, and in the whole flesh differentiating parenchyma and stone cells.

\subsubsection{Phenol buffer method}

Frozen pear flesh and skin ( $2 \mathrm{~kg}$ and $1 \mathrm{~kg}$, respectively) were suspended in chilled buffer $\left(2 \mathrm{~L}, 1.2 \mathrm{mM} \mathrm{CaCl}_{2}, 2.0 \mathrm{mM} \mathrm{MgCl}_{2}, 6.7 \mathrm{mM}\right.$ $\mathrm{KCl}, 60 \mathrm{mg} / \mathrm{L}$ ascorbic acid and $4 \mathrm{~g} / \mathrm{L}$ malic acid, sodium disulfite $1 \mathrm{~g} / \mathrm{L}$, adjusted to $\mathrm{pH} 3.5$ with $5 \mathrm{M} \mathrm{NaOH}$; this solution will be called 'buffer' in the following paragraphs) with Triton $\times 100(0.1 \mathrm{~g} / \mathrm{L})$ and mixed in a Kitchen blender until an homogenous mixture was obtained. The detergent was then washed off with chilled buffer until the washings were sugar-free (absence of sugars tested by the phenol-sulphuric method of Dubois, Gilles, Hamilton, Rebers, and Smith (1956). Cell walls were then suspended for $15 \mathrm{~min}$ in acetone: water $(60: 40, \mathrm{v}: \mathrm{v})$ to eliminate polyphenols and transferred to a G3 sintered glass filter. Excess solvent was removed by aspiration under vacuum, the remaining paste was suspended in four times its weight of phenol for $1 \mathrm{~h}$ at room temperature. The saturated phenol solution was removed by extensive washing with buffer on G3 sintered glass filter (until the phenol smell disappeared). The sample was finally solvent-exchanged in $50 \%$ acetone (three times), 75\% acetone (three times) and 100\% acetone (three times) then overnight in an oven at $40^{\circ} \mathrm{C}$ and ground. We obtained at this step CWM from the whole flesh (this sample was named FL) and CWM from skin (this sample was named SK).

To extract cell walls from stone cells and parenchyma cells separately, $2 \mathrm{~kg}$ of frozen pear flesh was used. The separation of stone cells from parenchymatous tissues was based on their higher density. After washing with acetone: water, the pulp was stored overnight at $4{ }^{\circ} \mathrm{C}$ in the same acetone: water solution. Stone cells sedimented and formed a distinctive yellow layer at the bottom of the container. The upper layer representing the parenchyma cells was carefully discarded and kept separately. Parenchyma cells (still containing some stone cells) were then centrifuged (20 min, 5000g) and collected carefully to further separate stone cells. The other extraction steps were applied to the two cell types as explained above and we obtained CWM from parenchyma cells (this sample was named PC) and CWM from stone cells (this sample was named ST).

\subsubsection{Sequential polysaccharide extractions}

The cell wall polysaccharides present in different CWM were extracted sequentially by ammonium oxalate, $\mathrm{Na}_{2} \mathrm{CO}_{3}, \mathrm{NaOH} 1 \mathrm{M}$, 
Version définitive du manuscrit publiée dans / Final version of the manuscript published in :

Carbohydrates Polymers (2017), Vol. 156, p. 152-164, DOI: 10.1016/j.carbpol.2016.09.019

Journal homepage : www.elsevier.com/locate/carbpol

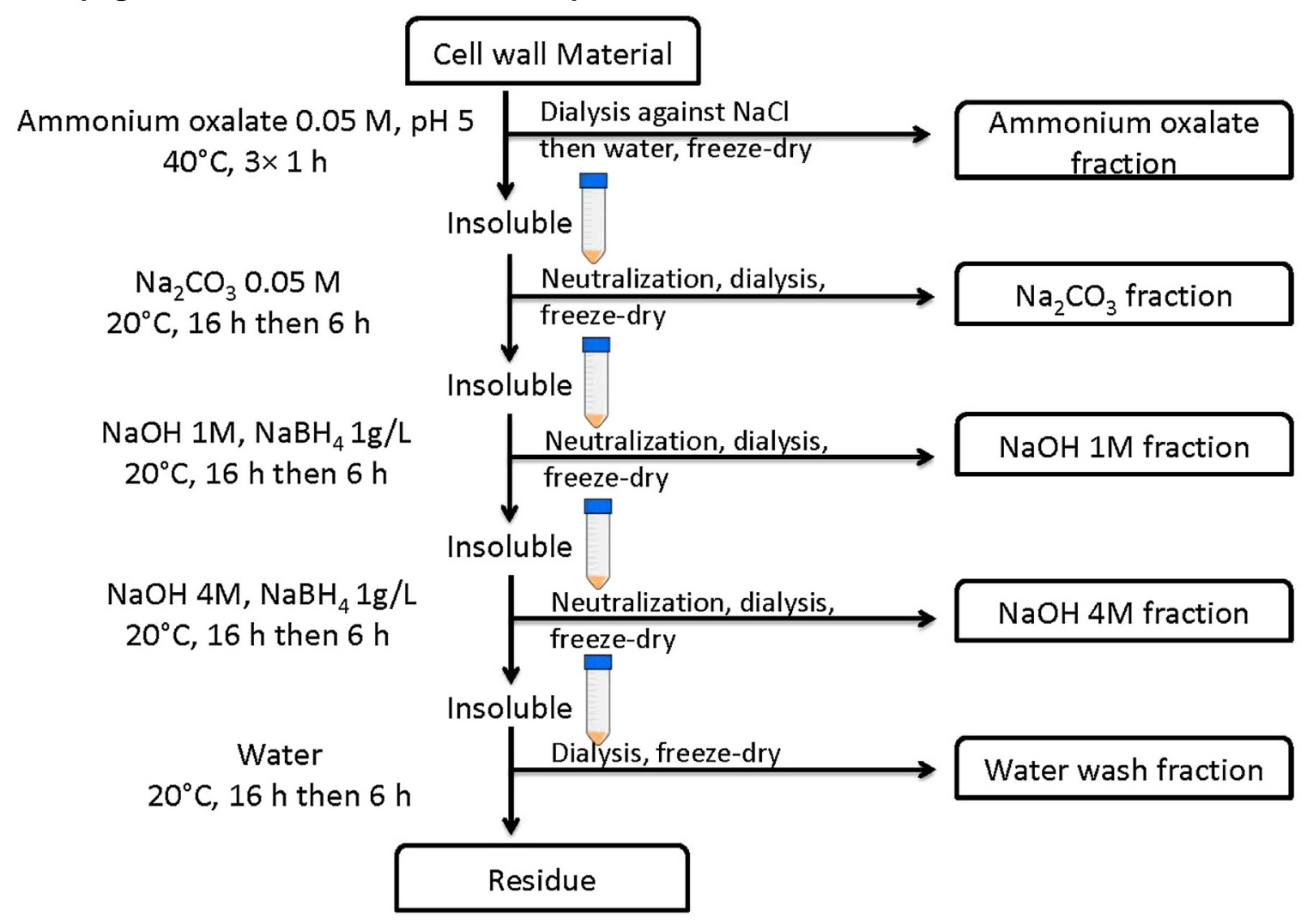

Fig. 1. Scheme of the sequential polysaccharide extractions from pear flesh, parenchyma cells, stone cells and skin at two maturity stages (ripe and overripe).

$\mathrm{NaOH} 4 \mathrm{M}$ and water according to a scheme by Renard and Ginies (2009). The fractionation procedure (Fig. 1) was done in triplicate.

For each sample, $1.5 \mathrm{~g}$ of CWM and $45 \mathrm{~mL}$ of ammonium oxalate $(0.05 \mathrm{M}, \mathrm{pH} 5)$ were incubated $1 \mathrm{~h}$ at $40^{\circ} \mathrm{C}$ under slow planetary agitation. The solid/liquid separation was carried by centrifugation ( $10 \mathrm{~min}$ at $13600 \mathrm{~g}$ for all consecutive extractions). This was repeated twice, and the three supernatants were pooled and dialyzed against $0.1 \mathrm{M} \mathrm{NaCl}$, then against water, and freeze-dried (this fraction was named ammonium fraction). The residue was extracted for $16 \mathrm{~h}$ with $0.05 \mathrm{M} \mathrm{Na}_{2} \mathrm{CO}_{3}$, then for the second time for $6 \mathrm{~h}$; the supernatants were pooled and neutralized with acetic acid to $\mathrm{pH} 4-5$, dialyzed against water and freeze-dried (this fraction was named $\mathrm{Na}_{2} \mathrm{CO}_{3}$ fraction). The residue was extracted with $1 \mathrm{M} \mathrm{NaOH}+1 \mathrm{~g} / \mathrm{L} \mathrm{NaBH}_{4}$ solution for $16 \mathrm{~h}$, and then for a second time for $6 \mathrm{~h}$; the supernatants were pooled and neutralized with acetic acid to $\mathrm{pH} 4-5$. Foam formation during neutralization due to hydrogen release was decreased by the addition of ethanol drops. The extract was dialyzed against water and freeze-dried (this fraction was named $\mathrm{NaOH} 1 \mathrm{M}$ fraction). The residue was extracted with $4 \mathrm{M} \mathrm{NaOH}+1 \mathrm{~g} / \mathrm{L} \mathrm{NaBH}_{4}$ solution for $16 \mathrm{~h}$. This step was repeated with an incubation time of $6 \mathrm{~h}$. Supernatants were pooled, neutralized with acetic acid to $\mathrm{pH}$ 4-5. Appearing foam was lessened by addition of a few drops of ethanol. The extract was dialyzed against water and freeze-dried (this fraction was named $\mathrm{NaOH} 4 \mathrm{M}$ fraction). The residue was extracted with water until the washing water was no longer alkaline. The washing waters were pooled, dialyzed and freeze-dried (this fraction was named water wash). The final solid residue was also freeze-dried (this fraction was named residue).

\subsection{Mid infrared spectroscopy (MIR)}

FL, SK, PC and ST were analyzed by ATR-Diamond spectrum acquisition. MIR spectra were collected at room temperature with a Tensor 27 FT-IR spectrometer (Bruker Optics, Wissembourg, France) equipped with a single-reflectance horizontal ATR cell (Golden Gate equipped with diamond crystal, Bruker Optics). CWM were placed on the ATR as powder and were pressed with a system press tip flap. The samples were scanned at wavenumbers ranging from 4000 to $600 \mathrm{~cm}^{-1}$ and corrected against the background spectrum of air. Each spectrum was obtained by taking the average of 16 scans. Three spectra were acquired for each sample to evaluate their heterogeneity. The absorption ranged between 2400 and $2200 \mathrm{~cm}^{-1}$, due to carbon dioxide, was discarded prior the calculation. The data treatment applied here on spectral data is described by Bertrand, Courcoux, Autran, Meritan, and Robert (1990). Principal Component Analysis (PCA) was first applied on the raw spectral data, using 20 components, sufficient to include the total variance. Factorial discriminant analysis (FDA) was then applied using the principal components of the PCA. The analysis of discriminant patterns allows the identification of the spectral area involved in the sample discrimination according to the cell wall or the maturity. Spectral pre-processing and data treatment using multivariate analyses were performed with Matlab 7.5 (Mathworks Inc. Natick, MA) software using SAISIR package (Cordella \& Bertrand, 2014). The MIR data were transformed with standard normal variate (SNV) to correct multiplicative interferences and variations in baseline shift before any multivariate analysis.

\subsection{Scanning electron microscopy (SEM)}

Dried and homogenized PC and ST for each maturity were mounted on specimen stubs with double-sided, carbonconductive, adhesive tape and covered with $20 \mathrm{~nm}$ gold layers by ion sputtering (Balzers SCD 004 Sputter Coater, Balzers, Bal Tec. AG, Furstentum, Lichtenstein). Samples were examined by a Philips XL30 (FEI/Philips, Eindhoven, The Netherlands) scanning electron microscope operated at an accelerating voltage of $10 \mathrm{kV}$. 
Version définitive du manuscrit publiée dans / Final version of the manuscript published in :

Carbohydrates Polymers (2017), Vol. 156, p. 152-164, DOI: 10.1016/j.carbpol.2016.09.019

Journal homepage : www.elsevier.com/locate/carbpol

A

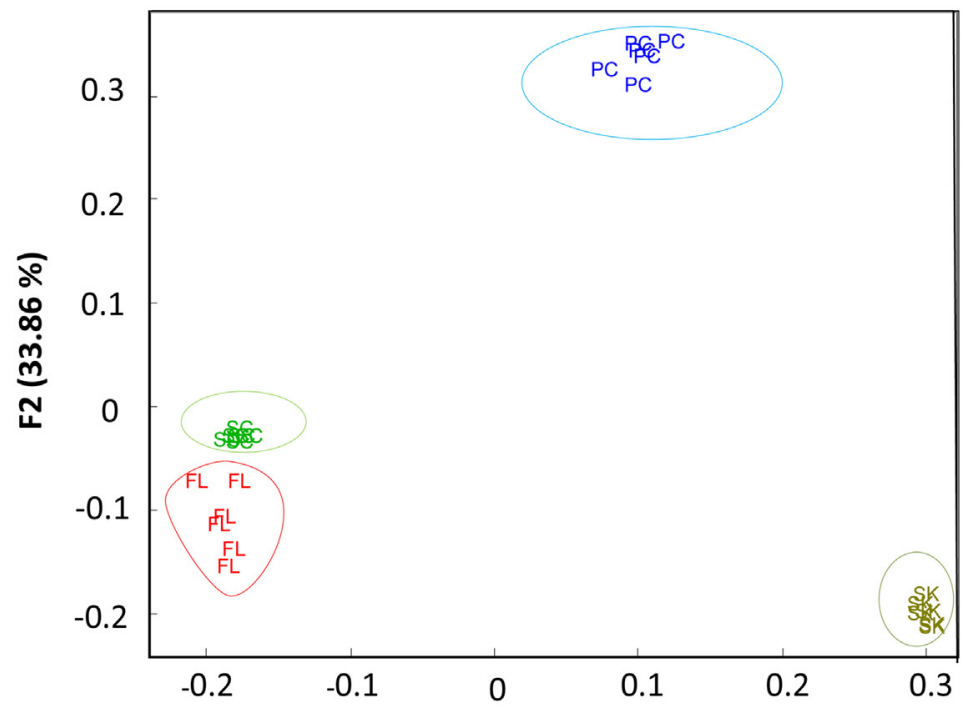

F1 (34.06\%)

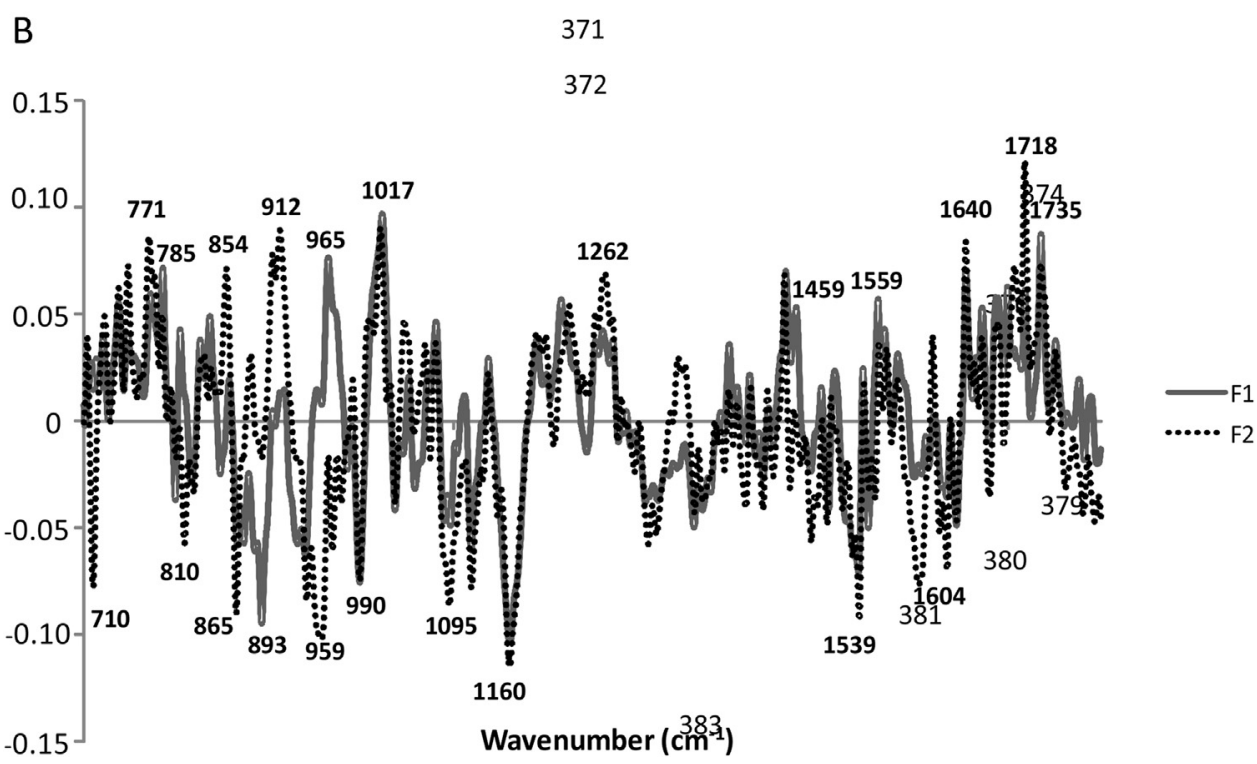

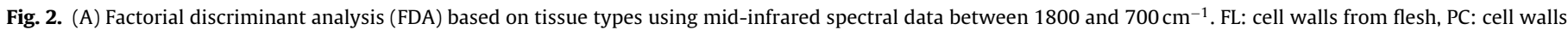
from parenchyma cells, ST: cell walls from stone cells, SK: cell walls from skin. (B) Discriminant patterns of the two first factorial scores.

\subsection{Analytical}

All analyses were carried out in triplicate.

\subsubsection{Neutral sugar composition}

Neutral sugars were analyzed as alditol acetates after acid hydrolysis with 2 options. For samples including cellulose, about $10 \mathrm{mg}$ were submitted to prehydrolysis with $250 \mu \mathrm{L} 72 \%$ sulphuric acid for $1 \mathrm{~h}$ at room temperature (Saeman, Moore, Mitchell, \& Millett, 1954), then diluted to $1 \mathrm{M}$ sulphuric acid by addition of water and internal standard (inositol). For extracted polysaccharides, no prehydrolysis was carried out, samples were dissolved in $1 \mathrm{M}$ sulphuric acid with internal standard. All samples were hydrolyzed at $100^{\circ} \mathrm{C}$ for $3 \mathrm{~h}$, then derivatised to volatile alditol acetates (Englyst, Wiggins, \& Cummings, 1982). They were injected into a GC-FID HP 5890 Series II (Agilent, Inc., Palo Alto, USA) with a capillary column of $30 \mathrm{~m} \times 0.25 \mathrm{~mm}$ id coated with DB225 MS, $0.25 \mu \mathrm{m}$ film thickness (J\&W Scientific, Agilent, Inc., Palo Alto, USA). The conditions were as follows: temperature of injection $250^{\circ} \mathrm{C}$ in split mode (1:25 ratio); hydrogen as carrier gas at $45 \mathrm{~cm} / \mathrm{s}\left(215^{\circ} \mathrm{C}\right)$, column flow $1.3 \mathrm{~mL} / \mathrm{min}$, oven temperature $215^{\circ} \mathrm{C}$ (isothermal).

\subsubsection{Uronic acids content}

Uronic acids were measured spectrophotometrically (V-530 Jasco, Tokyo, Japan) by the $m$-hydroxydiphenyl assay as described by Blumenkrantz and Asboe-Hansen (1973) with galacturonic acid as external standard. Samples were prepared after acid hydrolysis for CWM and residue according to Saeman procedure (Saeman et al., 1954) and after saponification for ammonium extracts. $\mathrm{Na}_{2} \mathrm{CO}_{3}, \mathrm{NaOH} 1 \mathrm{M}, \mathrm{NaOH} 4 \mathrm{M}$ and water wash extracts, already deesterified, were simply dissolved in water. 
Version définitive du manuscrit publiée dans / Final version of the manuscript published in :

Carbohydrates Polymers (2017), Vol. 156, p. 152-164, DOI: 10.1016/j.carbpol.2016.09.019

\section{Journal homepage : www.elsevier.com/locate/carbpol}

\subsubsection{Methanol and degree of methylation}

Methanol was determined in CWM and ammonium fractions by stable isotope dilution Headspace-GC-MS (QP2010 Shimadzu Kyoto, Japan) after saponification as described in Renard and Ginies (2009).

\subsubsection{Lignin content}

Lignin was analyzed in CWM and final residues as described by Syros et al. (2004) with some modifications. Samples (10-15 mg) were digested in $1 \mathrm{~mL} \mathrm{25 \%}$ acetyl bromide in acetic acid containing $2.7 \%(\mathrm{v} / \mathrm{v})$ perchloric acid. Then, the mixture was incubated for $30 \mathrm{~min}$ at $70^{\circ} \mathrm{C} .10 \mu \mathrm{L}$ for each sample were added to $570 \mu \mathrm{L}$ of a solution of [17.24\% (v/v) $2 \mathrm{~N} \mathrm{NaOH}$ and $82.76 \%(\mathrm{v} / \mathrm{v})$ acetic acid] and $20 \mu \mathrm{L}$ of $7.5 \mathrm{M}$ hydroxylamine hydrochloride to stop the reaction. The volume was corrected to $2 \mathrm{~mL}$ with acetic acid and the absorbance was read at $280 \mathrm{~nm}$ using a spectrophotometer V-530 (Jasco, Tokyo, Japan). The lignin content was calculated from calibration curve with lignin alkali.

\subsubsection{Procyanidins content}

Some procyanidins remain bound to the cell walls after the phenol buffer preparation. They were measured by HPLC-DAD (CBM 20A, Shimadzu Kyoto, Japan) after thioacidolysis as described by Guyot et al. (2001) and Le Bourvellec et al. (2011). Calibration was achieved by injection of (+)-catechin and (-)-epicatechin solutions of known concentrations. The average degree of polymerisation (DP) of procyanidins was calculated as the molar ratio of all the flavan-3-ol units (thio ether adducts plus terminal units) to (-)epicatechin and (+)-catechin corresponding to terminal units.

\subsubsection{Acetic acid content}

Acetic acid was released by incubating CWM with $\mathrm{NaOH} 0.25 \mathrm{M}$ for $3 \mathrm{~h}$. Acetyl groups were quantitated using an acetic acid assay kit based on the use of acetyl-coenzyme A synthetase (Acetic acid, Acetyl-CoA Synthetase Format, Megazyme international, Ireland). Absorbance was determined at $340 \mathrm{~nm}$ and the acetic acid content was calculated from a linear calibration.

\subsubsection{Size exclusion of pectin fractions}

The hydrodynamic volume distribution of ammonium and $\mathrm{Na}_{2} \mathrm{CO}_{3}$ soluble pectin for each CWM was studied by HPSEC system (Jasco, Tokyo, Japan). Separation were achieved using two columns in series, an OH-pack SB-802 HQ $(300 \mathrm{~mm} \times 0.8 \mathrm{~mm}$ ID) (Showa Denko Europe, Munich, Germany) and a TSK-Gel PWXL $\left(300 \times 7.8 \mathrm{~mm}\right.$ ID) (Tosohaas, Stuttgart, Germany) at $35^{\circ} \mathrm{C}$ in combination with a guard column $(40 \times 6.0 \mathrm{~mm}$ i.d. $)$ TSK-Gel PWXL (Tosohaas).The columns were eluted by sodium acetate/acetic acid buffer $0.4 \mathrm{M} \mathrm{pH} 3.6$ with a flow of $0.8 \mathrm{~mL} / \mathrm{min}$. The calibration curve was obtained using dextran standards: T500, T70, T40, T10, glucose.

\subsection{Statistics}

Results are presented as mean values of triplicates. The analytical reproducibility of the results was determined as pooled standard deviations (Pooled SD). This last was calculated for each series of replicates using the sum of individual variances weighted by the individual degrees of freedom (Box, Hunter, \& Hunter, 1978). ANOVA and Principal Component Analysis (PCA) were performed on chemical data using the Excel stat package of Microsoft Excel.

\section{Results and discussion}

\subsection{Texture evolution during overripening}

Due to the heterogeneity of pear flesh with the presence of different cell types, the work to limit was chosen as more illustrative of overall fruit texture than the maximum force which might be due only to a cluster of stone cells in the path of the probe. It was considered as the most representative variable of fruit firmness. The work to limit decreased from the ripe to overripe pears, with respectively $83 \pm 1710^{-4} \mathrm{~J}$ and $70 \pm 1010^{-4} \mathrm{~J}$ after 8 days of storage.

\subsection{General characteristics of cell walls}

The Mid Infrared Spectroscopy (MIR) and Scanning electron microscopy (SEM) were used as non destructive methods to obtain the general characteristics of different pear cell walls, taking into account the tissue type and the maturity stage.

\subsubsection{Mid infrared spectroscopy}

Infrared spectroscopy is one of the most widely used spectroscopic tools for the study of polymers, which provides information about the sample component structures. The method is simple, non destructive, fast and exhibits high sensitivity. It was used here to highlight potential differences between the pear cell walls from the different tissues at two maturity stages. Infrared spectroscopy analysis is based on the specific absorptions at different wavenumbers in mid infrared regions of various functional groups such as carboxylate $\left(\mathrm{COO}^{-}\right)$and ester carbonyl (CO) groups (Kyomugasho, Christiaens, Shpigelman, Van Loey, \& Hendrickx, 2015). Averaged spectra obtained from all pear tissues were ranged between 1800 and $700 \mathrm{~cm}^{-1}$. This region includes the most informative spectral region and presents the characteristic band for the main polysaccharides from cell walls (Coimbra, Barros, Barros, Rutledge, \& Delgadillo, 1998; Ferreira, Barros, Coimbra, \& Delgadillo, 2001; Kačuráková, Capek, Sasinkova, Wellner, \& Ebringerova, 2000; Kačuráková \& Wilson, 2001). All spectra were very similar, they did not show visually change according to tissue type and maturity stage (Supplementary data). Pear cell wall spectra were close to those obtained on apple cell wall during fruit development by Szymanska-Chargot, Chylinska, Kruk, and Zdunek (2015).

However, the ANOVA analysis performed showed that the tissue type effect was four times higher than the ripening one (data not shown). As the aim was to highlight differences, it was decided to apply a FDA using the principal components of the PCA. Even if the sample discrimination was obtained from the tenth principal components, the FDA using the 20 principal components allowed the best discrimination. The two first factorial scores from FDA (Fig. 2A) together explained about 68\% of the variability (F1 34.06\%, F2 33.86\%). Flesh, skin, parenchyma and stone cells (FL, SK, PC and ST) were pooled in four discrete groups. FL, ST and SK were scattered along the first axis F1, while PC was separated from the others along the F2 axis. F3 explain also $32.07 \%$ of the variability (data not shown) and discriminated FL and ST. The discriminant patterns were extracted (Fig. 2B) in order to identify the most relevant wavelength for this discrimination. This discrimination is expected to be mainly related to the presence of functional groups characteristic of pear cell wall polysaccharides (Ferreira et al., 2001). It could be influenced also by bands characteristic of cutin and waxes especially for skin (Heredia-Guerrero et al., 2016) and lignin for stone cells (Kačuráková \& Wilson, 2001). Some absorption bands appeared to be specific in particular of FL and ST such as 710, $810,865,893,959,1095,1160,1539$ and $1604 \mathrm{~cm}^{-1}$. Positive peaks along $\mathrm{F} 1$ at $785,965,1495,1559$ and $1735 \mathrm{~cm}^{1}$ were specific of SK whereas, positive peaks along F2 such as 771, 854, 912, 1262, 1640 and $1718 \mathrm{~cm}^{-1}$ were characteristic of PC. Most important wavelengths characteristic for discriminated groups indicated a variable composition depending on tissular origin of cell walls. $1160 \mathrm{~cm}^{-1}$ is characteristic of antisymmetric stretching of $\mathrm{C}-\mathrm{O}-\mathrm{C}$ in cellulose structure and $1604 \mathrm{~cm}^{-1}$ band of $\mathrm{COO}^{-}$antisymmetric stretching polygalacturonic acid and pectin ester groups (Szymanska-Chargot et al., 2015). A contribution coming from pectin and cellulose 


\section{Journal homepage : www.elsevier.com/locate/carbpol}

could be present between 1050 and $1015 \mathrm{~cm}^{-1}$ (Fasoli et al., 2016). $1735 \mathrm{~cm}^{-1}$ is characteristic of $\mathrm{C}=\mathrm{O}$ stretching in aliphatic polyesters in cuticle structure (Fasoli et al., 2016). The detailed composition of pear cell walls will be given following biochemical analysis.

\subsubsection{Scanning electron microscopy}

Pears are one of the few fruits that have a heterogeneous flesh due to the simultaneous presence of parenchyma and stone cells. The SEM was used to illustrate the different aspects between these two cell types for ripe and overripe pears. Parenchyma cells were large cells with thin cell walls (Fig. 3A). ST appeared in SEM as clusters of small cells with thick cell walls (Fig. 3B) connected by simple pits (Fig. 3E). Micrographs obtained from European and Asian pears (Ferreira et al., 2008; Tao, Khanizadeh, Zhang, \& Zhang, 2009; Yan et al., 2014) show the same structures of stone cells and parenchyma cells. During ripening, changes involved a loss of cell definition especially for stone cells clusters and less for parenchyma cells (Figs. 3C, D). SEM micrographs done by Almeida, Gomes, and Pintado (2009) on fresh tissue from "Rocha" pear flesh at two maturity stages showed cell walls that these authors described as being stiff in crispy pears and becoming flaccid in soft pears.

\subsection{Cell walls: yields and compositions}

Table 1 summarizes yields and compositions of the different tissues at both maturity stages (ripe and overripe pears).

\subsubsection{Cell wall yields}

The CWM yields for fruit flesh varied from $15.3 \mathrm{mg} / \mathrm{g}$ fresh weight (FW) (ripe) to $19.3 \mathrm{mg} / \mathrm{g} \mathrm{FW}$ (overripe), and were higher by about 6 times (117.3-96.1 mg/g FW) for skin. The PC yields varied from $3.4 \mathrm{mg} / \mathrm{g}$ (ripe) to $4.7 \mathrm{mg} / \mathrm{g}$ (overripe) fresh weight of total pear flesh, and were higher by about 3 times $(12.9-15.1 \mathrm{mg} / \mathrm{g} \mathrm{FW})$ for ST, i.e. approximately $3 / 4$ of the cell walls in "De Cloche" pear flesh came from stone cells. In spite of the separation procedure, there was little loss of cell walls during centrifugations and the total yields of FL correspond to the sum of yields of PC and ST. Few data are available on the extraction of the cell walls from stone cells and parenchyma cells separately. Stone cells represented $37 \%$ of guava cell walls in the endocarp and 78\% in the mesocarp (Marcelin et al., 1993).

The yields of FL from "De Cloche" perry pears were lower than those of cell walls isolated as alcohol-insoluble solids (AIS) from "Blanquilla" pears (30 mg/g FW) (Martin-Cabrejas et al., 1994a,b), "Gieser Wildeman" pears (23 mg/g FW) (Renard, 2005a), "Bartlett" pears (25 mg/g FW) (Raffo et al., 2011) and "William" pears $(28 \mathrm{mg} / \mathrm{g}$ FW) (Le Bourvellec et al., 2013). In comparison, yields of cell walls prepared using the phenol: buffer method from cider apple were $27 \mathrm{mg} / \mathrm{g}$ FW of apple parenchyma (Le Bourvellec, Guyot, \& Renard, 2004). For SK, the yields (117.3-96.1 mg/g FW) were also lower than skin cell wall isolated as alcohol-insoluble solids (AIS) from "Blanquilla” pears (121-142 mg/g FW) (Martin-Cabrejas et al., 1994a,b). The lower yields obtained for FL and SK with the phenol buffer method could be due to a better elimination of protein and polyphenols (Renard, 2005b). The yields slightly increased with maturity except for SK.

\subsubsection{Cell wall compositions}

3.3.2.1. Elimination of intracellular polyphenols. CWM were isolated by a phenol: buffer method to obtain cell walls devoid of protein and with low procyanidin contents (Le Bourvellec et al., 2004). Procyanidins bind spontaneously to the cell walls during extraction (Renard, Baron, Guyot, \& Drilleau, 2001) but the cell wall preparation method used here specifically limits this phenomenon(Renard, 2005b). The amount of bound procyanidins varied between 1 and $3 \mathrm{mg} / \mathrm{g}$ of CWM. However, significant differences were observed between ripe and overripe pears. Both procyanidin contents and their degree of polymerization increased from ripe to overripe essentially for FL, PC and ST (Table 1). For SK, both the amounts of procyanidins and their degree of polymerization were still stable during maturity and only procyanidins with low DP (7- 9 for ripe and overripe pears respectively) were bound. This also reflects the different polyphenols compositions in skin and flesh (Supplementary data). Increasing binding between procyanidins and cell walls might be due to loss of cell integrity in overripe fruit (Bindon, Madani, Pendleton, Smith, \& Kennedy, 2014). Furthermore, affinity between cell walls and procyanidins could be modified by ripening as described for grape skin cell walls and procyanidins (Bindon \& Kennedy, 2011).

3.3.2.2. Polysaccharides composition. The main components for different pear cell walls at the two maturity stage were glucose (166-247 mg/g CWM), xylose (97-213 mg/g CWM), uronic acids (71-177 mg/g CWM) and arabinose (44-110 mg/g CWM). ST and FL had similar compositions than PC with slightly less glucose, uronic acids and arabinose, high xylose, as well as higher lignin content. Tao et al. (2009) quantified in dried stone cells of two Pyrus species "Jingaisu" and "Kousui" 298 and $245 \mathrm{mg} / \mathrm{g}$ of lignin respectively. SK were richer in lignin and xylose and had lower amounts of uronic acids. The degree of methylation of pectins was $>50 \%$, reaching $80 \%$ in FL and PC. Galactose was present at higher concentration in the FL and PC (40-70 mg/g CWM). Mannose, rhamnose and fucose were minor components (1-10 mg/g CWM). This composition was close to those reported in pears (Le Bourvellec et al., 2013; Martin-Cabrejas et al., 1994a,b; Renard, 2005a). In general, the composition of pear cell walls shows high amounts of glucose and xylose that can be attributed to the presence of stone cells. Lignified cell walls from pears are rich in xylans and cellulose (Ben-Arie et al., 1979; Martin-Cabrejas et al., 1994a,b). During overripening, uronic acids and arabinose tended to decrease, essentially for FL and PC. Ahmed and Labavitch (1980) showed extensive loss of arabinose from cell wall polysaccharides from "Bartlett" pears during ripening. High levels of acetyl groups were found in pear cell walls especially for ST ( $>60 \mathrm{mg} / \mathrm{g}$ CWM). These high amounts could be explained by the richness of pear cell walls in xylose and lignin. $O$-acetyl-substituents can be present on almost cell wall polymers, and in particular, hemicelluloses (xyloglucan, xylan and glucomannan) and pectins are often acetylated (Gille \& Pauly, 2012; Pawar et al., 2016). Lignin can also be $O$ - acetylated (Del Río et al., 2008).

\subsection{Sequential extractions: yields and characterizations}

The polysaccharide compositions of the CWM of ripe and overripe "De Cloche" pears were investigated using a fractional extraction scheme (Fig. 1). Carbohydrate compositions of all extracts from ripe and overripe pears are given in Table 2, typical sugar ratios in Table 3 and Fig. 4 shows the corresponding PCA analysis.

ANOVA (Table 2) was performed using the sequential extraction results for four cell walls (FL, ST, PC and SK), six extracts (Ammonium oxalate, $\mathrm{Na}_{2} \mathrm{CO}_{3}, \mathrm{NaOH} 1 \mathrm{M}, \mathrm{NaOH} 4 \mathrm{M}$, water wash and residue fractions), two maturity stages (ripe and overripe). ANOVA indicated that the type of extract was the most significant factor, tissue type and ripeness had also significant effect. Arabinose, xylose, galactose, uronic acids and mannose were the most relevant compounds for differentiating maturity. The interaction 'tissue type $\times$ maturity' influenced significantly uronic acids and neutral sugars from pectic polysaccharides such as rhamnose, fucose, arabinose and galactose. Xylose and glucose, the most two neutral sugars characteristic of pear cell walls, had a very high difference with maturity and tissue type. In the PCA analysis the two first axes (PC1 and PC2) explained close to $65 \%$ of the total variance 
Version définitive du manuscrit publiée dans / Final version of the manuscript published in :

Carbohydrates Polymers (2017), Vol. 156, p. 152-164, DOI: 10.1.016/j.carbpol.2016.09.019

Journal homepage : www.elsevier.com/locate/carbpol

Table 2

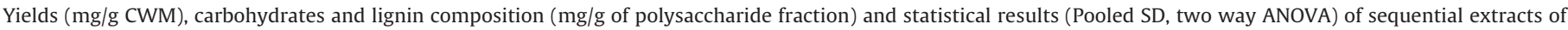
flesh, parenchyma cells, stone cells and skin from ripe and overripe pears.

\begin{tabular}{|c|c|c|c|c|c|c|c|c|c|c|c|c|c|c|}
\hline & Maturity & Fractions & Yields & Rha & Fuc & Ara & Xyl & Man & Gal & Glc & AUA & $\mathrm{MeOH}$ & $\mathrm{DM}(\%)$ & Lig \\
\hline \multirow[t]{12}{*}{ FL } & \multirow[t]{6}{*}{ Ripe } & Ammonium $0.05 \mathrm{M}$ & 36 & 4 & 1 & 339 & 13 & 0 & 50 & 4 & 146 & 23 & 87 & nd \\
\hline & & $\mathrm{Na}_{2} \mathrm{CO}_{3} 0.05 \mathrm{M}$ & 87 & 12 & 1 & 115 & 14 & 0 & 43 & 0 & 543 & nd & nd & nd \\
\hline & & $\mathrm{NaOH} 1 \mathrm{M}$ & 17 & 9 & 18 & 91 & 140 & 7 & 85 & 141 & 20 & nd & nd & nd \\
\hline & & $\mathrm{NaOH} 4 \mathrm{M}$ & 149 & 4 & 7 & 43 & 49 & 7 & 39 & 60 & 14 & nd & nd & nd \\
\hline & & Water wash & 61 & 3 & 1 & 33 & 25 & 1 & 17 & 12 & 29 & nd & nd & nd \\
\hline & & Residue & 622 & 3 & 0 & 35 & 183 & 0 & 13 & 238 & 24 & nd & nd & 155 \\
\hline & \multirow[t]{6}{*}{ Overripe } & Ammonium $0.05 \mathrm{M}$ & 23 & 8 & 5 & 115 & 26 & 1 & 44 & 31 & 301 & 49 & 90 & nd \\
\hline & & $\mathrm{Na}_{2} \mathrm{CO}_{3} 0.05 \mathrm{M}$ & 65 & 11 & 1 & 72 & 14 & 0 & 30 & 0 & 532 & nd & nd & nd \\
\hline & & $\mathrm{NaOH} 1 \mathrm{M}$ & 30 & 8 & 19 & 48 & 118 & 5 & 71 & 139 & 67 & nd & nd & nd \\
\hline & & $\mathrm{NaOH} 4 \mathrm{M}$ & 50 & 16 & 20 & 91 & 141 & 24 & 103 & 179 & 33 & nd & nd & nd \\
\hline & & Water wash & 28 & 21 & 3 & 148 & 101 & 0 & 79 & 19 & 255 & nd & nd & nd \\
\hline & & Residue & 698 & 4 & 0 & 20 & 190 & 0 & 11 & 222 & 32 & nd & nd & 189 \\
\hline \multirow[t]{12}{*}{ PC } & \multirow[t]{6}{*}{ Ripe } & Ammonium $0.05 \mathrm{M}$ & 29 & 6 & 4 & 324 & 20 & 1 & 71 & 26 & 343 & 54 & 86 & nd \\
\hline & & $\mathrm{Na}_{2} \mathrm{CO}_{3} 0.05 \mathrm{M}$ & 87 & 10 & 1 & 63 & 11 & 0 & 25 & 3 & 621 & nd & nd & nd \\
\hline & & $\mathrm{NaOH} 1 \mathrm{M}$ & 14 & 8 & 27 & 69 & 135 & 8 & 104 & 204 & 20 & nd & nd & nd \\
\hline & & $\mathrm{NaOH} 4 \mathrm{M}$ & 75 & 13 & 27 & 81 & 153 & 26 & 118 & 235 & 59 & nd & nd & nd \\
\hline & & Water wash & 61 & 20 & 3 & 175 & 54 & 0 & 100 & 19 & 350 & nd & nd & nd \\
\hline & & Residue & 513 & 9 & 1 & 74 & 148 & 1 & 43 & 278 & 62 & nd & nd & 208 \\
\hline & \multirow[t]{6}{*}{ Overripe } & Ammonium $0.05 \mathrm{M}$ & 20 & 13 & 8 & 225 & 43 & 2 & 81 & 62 & 432 & 66 & 84 & nd \\
\hline & & $\mathrm{Na}_{2} \mathrm{CO}_{3} 0.05 \mathrm{M}$ & 82 & 14 & 1 & 78 & 18 & 0 & 34 & 3 & 629 & nd & nd & nd \\
\hline & & $\mathrm{NaOH} 1 \mathrm{M}$ & 51 & 23 & 9 & 187 & 88 & 0 & 110 & 57 & 275 & nd & nd & nd \\
\hline & & $\mathrm{NaOH} 4 \mathrm{M}$ & 92 & 10 & 25 & 59 & 148 & 28 & 95 & 210 & 38 & nd & nd & nd \\
\hline & & Water wash & 30 & 10 & 32 & 58 & 154 & 10 & 112 & 246 & 43 & nd & nd & nd \\
\hline & & Residue & 557 & 11 & 2 & 80 & 156 & 0 & 44 & 342 & 74 & nd & nd & 207 \\
\hline \multirow[t]{12}{*}{ SC } & \multirow[t]{6}{*}{ Ripe } & Ammonium $0.05 \mathrm{M}$ & 22 & 8 & 4 & 278 & 21 & 4 & 67 & 26 & 287 & 40 & 76 & nd \\
\hline & & $\mathrm{Na}_{2} \mathrm{CO}_{3} 0.05 \mathrm{M}$ & 66 & 15 & 2 & 156 & 22 & 1 & 65 & 2 & 527 & nd & nd & nd \\
\hline & & $\mathrm{NaOH} 1 \mathrm{M}$ & 20 & 13 & 24 & 96 & 307 & 9 & 108 & 184 & 60 & nd & nd & nd \\
\hline & & $\mathrm{NaOH} 4 \mathrm{M}$ & 60 & 9 & 16 & 64 & 111 & 19 & 74 & 134 & 16 & nd & nd & nd \\
\hline & & Water wash & 41 & 29 & 3 & 292 & 146 & 0 & 137 & 13 & 208 & nd & nd & nd \\
\hline & & Residue & 631 & 5 & 0 & 21 & 321 & 0 & 12 & 340 & 13 & nd & nd & 384 \\
\hline & \multirow[t]{6}{*}{ Overripe } & Ammonium $0.05 \mathrm{M}$ & 10 & 6 & 4 & 109 & 20 & 2 & 37 & 27 & 244 & 36 & 81 & nd \\
\hline & & $\mathrm{Na}_{2} \mathrm{CO}_{3} 0.05 \mathrm{M}$ & 69 & 10 & 1 & 80 & 13 & 0 & 35 & 0 & 644 & nd & nd & nd \\
\hline & & $\mathrm{NaOH} 1 \mathrm{M}$ & 26 & 6 & 17 & 43 & 128 & 5 & 65 & 132 & 65 & nd & nd & nd \\
\hline & & $\mathrm{NaOH} 4 \mathrm{M}$ & 33 & 12 & 18 & 64 & 122 & 20 & 86 & 157 & 57 & nd & nd & nd \\
\hline & & Water wash & 58 & 9 & 2 & 73 & 45 & 0 & 38 & 11 & 141 & nd & nd & nd \\
\hline & & Residue & 640 & 4 & 0 & 21 & 173 & 0 & 14 & 212 & 23 & nd & nd & 402 \\
\hline \multirow[t]{17}{*}{ SK } & \multirow[t]{6}{*}{ Ripe } & Ammonium $0.05 \mathrm{M}$ & 36 & 4 & 1 & 366 & 10 & 0 & 37 & 6 & 159 & 29 & 100 & nd \\
\hline & & $\mathrm{Na}_{2} \mathrm{CO}_{3} \quad 0.05 \mathrm{M}$ & 55 & 13 & 2 & 217 & 8 & 2 & 46 & 1 & 523 & nd & nd & nd \\
\hline & & $\mathrm{NaOH} 1 \mathrm{M}$ & 19 & 12 & 15 & 84 & 161 & 25 & 88 & 154 & 28 & nd & nd & nd \\
\hline & & $\mathrm{NaOH} 4 \mathrm{M}$ & 26 & 21 & 25 & 171 & 167 & 63 & 155 & 256 & 16 & nd & nd & nd \\
\hline & & Water wash & 12 & 18 & 5 & 177 & 143 & 9 & 83 & 44 & 65 & nd & nd & nd \\
\hline & & Residue & 716 & 4 & 0 & 31 & 177 & 1 & 13 & 178 & 48 & nd & nd & 331 \\
\hline & \multirow[t]{6}{*}{ Overripe } & Ammonium $0.05 \mathrm{M}$ & 21 & 4 & 1 & 173 & 7 & 3 & 24 & 13 & 268 & 39 & 80 & nd \\
\hline & & $\mathrm{Na}_{2} \mathrm{CO}_{3} 0.05 \mathrm{M}$ & 51 & 8 & 1 & 107 & 5 & 1 & 23 & 1 & 536 & nd & nd & nd \\
\hline & & $\mathrm{NaOH} 1 \mathrm{M}$ & 20 & 7 & 9 & 39 & 103 & 12 & 44 & 84 & 26 & nd & nd & nd \\
\hline & & $\mathrm{NaOH} 4 \mathrm{M}$ & 23 & 12 & 13 & 77 & 84 & 33 & 69 & 122 & 24 & nd & nd & nd \\
\hline & & Water wash & 30 & 15 & 1 & 159 & 49 & 0 & 44 & 6 & 163 & nd & nd & nd \\
\hline & & Residue & 647 & 3 & 0 & 15 & 163 & 1 & 7 & 157 & 24 & nd & nd & 334 \\
\hline & Pooled SD & & 10.0 & 0.7 & 0.5 & 7.4 & 6.0 & 0.9 & 3.2 & 6.9 & 13.3 & 0.7 & 1 & 10.9 \\
\hline & \multirow[t]{4}{*}{ ANOVA } & Extract & $4433^{* * *}$ & $234^{* * *}$ & $2065^{* * *}$ & $718^{* * *}$ & $1108^{* * *}$ & $1163^{* * *}$ & $627^{* * *}$ & $1553^{* * *}$ & $1949^{* * *}$ & $4872^{* * *}$ & $5784^{* * *}$ & $877^{* * *}$ \\
\hline & & Tissue & $12^{* * * *}$ & $56 * * *$ & $319^{* * *}$ & $62 * * *$ & $79^{* * *}$ & $231^{* * *}$ & $192^{* * *}$ & $166^{* * *}$ & $109^{* * *}$ & $100 * * *$ & $4 * *$ & $32^{* * *}$ \\
\hline & & Maturity & $5 *$ & 2 & 2 & $590^{* * *}$ & $107^{* * *}$ & $25^{* * *}$ & $169^{* * *}$ & $7 * *$ & $65^{* * *}$ & $85^{* * *}$ & 2 & 0.9 \\
\hline & & Tissue * Maturity & $3 *$ & $160^{* * *}$ & $121^{* * *}$ & $68 * * *$ & $184^{* * *}$ & $82^{* * *}$ & $178^{* * *}$ & $77^{* * *}$ & $17^{* * *}$ & $25^{* * *}$ & $6 *$ & 0.3 \\
\hline
\end{tabular}

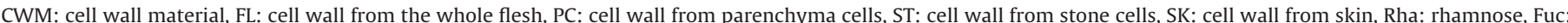

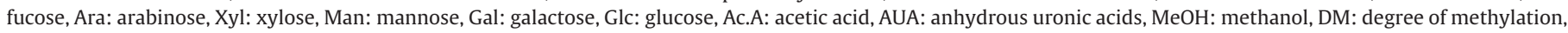
Lig: lignin, nd: not determined.

Pooled SD: pooled standard deviation (degree of freedom: 96)

Fisher's Value F value, $\mathrm{P} \leq 0.05:^{*}, \mathrm{P} \leq 0.01$ : $^{* *}, \mathrm{P} \leq 0.001$ : $^{* * *}$

Extract: Ammonium oxalate fraction, $\mathrm{Na}_{2} \mathrm{CO}_{3}$ fraction $\mathrm{NaOH} 1 \mathrm{M}$ fraction, $\mathrm{NaOH} 4 \mathrm{M}$ fraction, Water wash fraction and Residue fraction.

Tissue: Flesh, parenchyma cells, stone cells and skin.

Maturity: Ripe and overripe stages.

(Fig. 4A).Uronic acids, methanol and the DM contents were strongly correlated. Xylose and glucose were also strongly correlated indicating co-occurrence of xylans and cellulose in the residues, as were fucose and mannose, indicating co-extraction of xyloglucans and mannans in hemicellulose extracts. The evolution of lignin during overripening was correlated with xylose and glucose (Fig. 4A). The scatter plot (Fig. 4B) differentiated pectic, hemicellulosic and cellulosic extracts along the PC 1 axis which correspond to about 40\% of the variability. In fact, Fig. 4B showed a clear differentiation of the different type of fractions with separation of pectic extracts,
(Ammonium oxalate extract and diluted alkali soluble pectin) and hemicellulosic extract $(\mathrm{NaOH} 1 \mathrm{M}$ and $4 \mathrm{M})$ while the water wash fraction had intermediate composition, and residues were clearly separated.

\subsubsection{Composition of pectic extracts}

Three of the extracts were clearly pectic in nature: the first two (ammonium oxalate and $\mathrm{Na}_{2} \mathrm{CO}_{3}$ ), in which uronic acids and arabinose were predominant, and also the water wash after the hemicellulose extraction, in which galactose and arabinose were 
Version définitive du manuscrit publiée dans / Final version of the manuscript published in :

Carbohydrates Polymers (2017), Vol. 156, p. 1.52-164, DOI: 10.1016/j.carbpol.2016.09.019

Journal homepage : www.elsevier.com/locate/carbpol

Table 3

Characteristic sugar ratios in the different polysaccharide fractions from the cell walls of different pear tissues at two maturity stages (ripe and overripe fruit).

\begin{tabular}{|c|c|c|c|c|c|c|c|c|c|}
\hline & \multirow[b]{2}{*}{ Ratios } & \multicolumn{2}{|l|}{ FL } & \multicolumn{2}{|l|}{ PC } & \multicolumn{2}{|l|}{ SC } & \multicolumn{2}{|l|}{ SK } \\
\hline & & Ripe & Overripe & Ripe & Overripe & Ripe & Overripe & Ripe & Overripe \\
\hline \multirow[t]{2}{*}{ Ammonium oxalate $0.05 \mathrm{M}$} & AUA/Rha & 21 & 26 & 37 & 22 & 36 & 49 & 22 & 48 \\
\hline & $($ Ara + Gal $) /$ Rha & 74 & 17 & 55 & 20 & 55 & 37 & 74 & 46 \\
\hline \multirow[t]{2}{*}{$\mathrm{Na}_{2} \mathrm{CO}_{3} \quad 0.05 \mathrm{M}$} & AUA/Rha & 35 & 39 & 41 & 39 & 31 & 79 & 29 & 74 \\
\hline & $($ Ara + Gal $) /$ Rha & 13 & 10 & 8 & 9 & 16 & 18 & 19 & 23 \\
\hline \multirow[t]{2}{*}{ Water wash } & AUA/Rha & 8 & 11 & 17 & 4 & 6 & 16 & 4 & 10 \\
\hline & $($ Ara + Gal $) /$ Rha & 14 & 10 & 14 & 13 & 13 & 12 & 16 & 12 \\
\hline $\mathrm{NaOH} 1 \mathrm{M}$ & Xyl/Man & 30 & 28 & 27 & 14 & 42 & 32 & 8 & 12 \\
\hline $\mathrm{NaOH} 4 \mathrm{M}$ & Xyl/Man & 8 & 7 & 8 & 7 & 7 & 9 & 3 & 3 \\
\hline
\end{tabular}

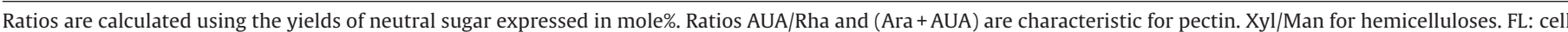

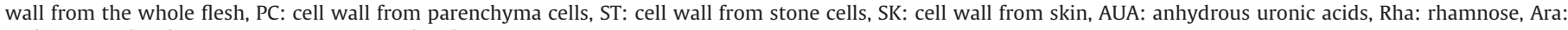
arabinose, Gal: galactose, Man: mannose, Xyl: xylose.

the main sugars. This last fraction could be attributed to two phenomena: presence of a pectic fraction closely associated, through its neutral side-chains (Renard, Voragen, Thibault, \& Pilnik, 1991; Zykwinska, Rondeau-Mouro, Garnier, Thibault, \& Ralet, 2006) to the cellulose microfibrils, and low pectin solubility at high salt concentrations. This material was thus loosened from the microfibrils during the concentrated alkali steps, but only became soluble when the ionic strength decreased.

Ammonium oxalate extracted little material from pear cell walls, the highest yields (3\%) being obtained for FL, PC and SK. The diluted alkali fraction $\left(\mathrm{Na}_{2} \mathrm{CO}_{3}\right)$ reached about $10 \%$ of PC (Table 2$)$. These low yields could be partially explained by loss of water soluble material during the CWM preparation, as previously shown by Renard (2005b). Martin-Cabrejas et al. (1994a,b) extracted pectin, using CDTA (Cyclohexanediaminotetraacetic acid) (12\%) and $\mathrm{Na}_{2} \mathrm{CO}_{3}$, from alcohol insoluble residue of Spanish pears. CDTA soluble pectin content was higher than obtained here with ammonium oxalate. In addition to different cell wall preparation methods, it should be noted that CDTA is often more efficient in pectin extraction but also very difficult to totally eliminate during analysis. In our case, ammonium oxalate was used for extracting pectin because it is easier to remove from cell wall fractions after dialysis despite its lower yield.

The highest uronic acid concentrations were found in $\mathrm{Na}_{2} \mathrm{CO}_{3}$ extracts $(>500 \mathrm{mg} / \mathrm{g})$. Ammonium oxalate fraction contained mainly arabinose (20-60 mol\%). This high arabinose indicated that the pear pectins were rich in hairy region. Modified hairy regions isolated from "Conference" pears contain about $40 \mathrm{~mol} \%$ of arabinose (Schols \& Voragen, 1994). In addition smaller but significant amounts of galactose were present $(30-70 \mathrm{mg} / \mathrm{g})$. Both ammonium oxalate and $\mathrm{Na}_{2} \mathrm{CO}_{3}$ fractions contained low content of xylose (8-21 mg/g) close to those reported by Martin-Cabrejas et al. (1994a,b) which might originate from xylogalacturonans (Wong, 2008). Uronic acids/rhamnose (AUA/Rha) and arabinose + galactose to rhamnose $((\mathrm{Ara}+\mathrm{Gal}) / \mathrm{Rha}))$ ratios were calculated for pectic fractions (ammonium oxalate, $\mathrm{Na}_{2} \mathrm{CO}_{3}$ and water wash fractions) (Table 3). The relative richness of the pectic material in homogalacturonans versus rhamnogalacturonans can be followed by the AUA/Rha ratio. As one might presume that most of the arabinose and galactose are associated with pectin's hairy regions, $($ Ara $+\mathrm{Gal}) /$ Rha was calculated to estimate the importance of the neutral side chains relative to the rhamnogalacturonan backbone (Table 3). The AUA/Rha ratio was higher in $\mathrm{Na}_{2} \mathrm{CO}_{3}$ than in ammonium oxalate fraction indicating the presence of pectins with a high contribution of homogalacturonans, especially for overripe ST and SK. Water wash fraction had the lowest AUA/Rha ratio ranging between 6 for overripe ST and 17 for ripe parenchyma cells, indicating presence of highly retained rhamnogalacturonans. The AUA/Rha ratio decreased with overripening in all three pectic extracts for PC but increased for ST and SK, probably indicat- ing loss of depolymerize homogalacturonans during overripening. Ammonium oxalate fraction contained rhamnogalacturonans with a high degree of branching ((Ara $+\mathrm{Gal}) /$ Rha $>17)$. The ripe FL and SK had the more branched rhamnogalacturonans. (Ara+Gal)/Rha ratio decreased mainly in overripe FL and PC showing a loss of side chain sugars (arabinose and galactose). Thus, overripening seemed to be associated with increased removal of rhamnogalacturonans side chains from the FL and PC tissues. This ratio did not change significantly for the other two pectin fractions. The ammonium oxalate extract showed the most differences as function of overripening.

The DM (Table 2) was only measured for the ammonium oxalate fraction as all other fractions were saponified during extraction. It was very high for pectin isolated from FL, PC and SK (>80\%), and only a little lower for ST (76\%). The presence of a high DM in chelator soluble fraction (CDTA) has been reported by Fischer, Arrigoni, and Amadò (1994) in ripe apple cell walls (DM close to 100\%). Le Bourvellec, Guyot, and Renard (2009) showed a lower DM in the ammonium oxalate fraction from cider apple (73\%) than this obtained in pear.

From the ripe to overripe pears, the main changes occurred in the pectic fractions (ammonium oxalate and $\mathrm{Na}_{2} \mathrm{CO}_{3}$ ). Both ammonium oxalate and $\mathrm{Na}_{2} \mathrm{CO}_{3}$ yields decreased in overripe $\mathrm{FL}$. The ammonium oxalate yields decreased in overripe PC, ST and SK while the $\mathrm{Na}_{2} \mathrm{CO}_{3}$ extracts were rather stable. Yoshioka, Aoba, and Kashimura (1992) report a decrease of chelator soluble pectin extracted with Ethylenediaminetetraacetic acid (EDTA) in apples and pears during softening while Martin-Cabrejas et al. (1994a,b) observe an increase in the water and CDTA soluble pectins and a decrease of the $\mathrm{Na}_{2} \mathrm{CO}_{3}$ extractions. In the same way, EDTA soluble pectin increase from the cell division period to overripening in Japanese pears (Pyrus serotina L.) (Yamaki et al., 1979). In the overripe pears, ammonium oxalate fraction lost about $50 \%$ of its arabinose for all tissues. The uronic acid content of this fraction increased at the overripe stage for FL, PC and SK, but it stayed relatively stable for ST. This increase of uronic acid content could be explained by the loss of arabinose and decrease in hairy regions, so that the polyuronides became relatively more abundant. Yoshioka et al. (1992) showed that the depolymerisation of polyuronide is relatively limited in pear. Galactose decreased for FL, ST and SK. In PC, the amounts of galactose increased slightly. (Ara + Gal)/Rha ratio was lower for the overripe pear indicating the degradation of neutral side chains of pectin during ripening. In the $\mathrm{Na}_{2} \mathrm{CO}_{3}$ fraction, arabinose and galactose seemed to have similar trends during ripening. In fact, their amounts decreased for FL, ST and SK and slightly increased for PC. The uronic acid amounts did not change for overripe FL, PC and SK. They increased slightly for ST. In "Bartlett" pears, the softening is marked by a loss of cell wall uronic acid attributed to the depolymerisation of rhamnogalacturonan (Dick \& Labavitch, 1989). Also, in pear, Martin-Cabrejas et al. (1994a,b) find that ripening is accompanied by a decrease in cell 
Version définitive du manuscrit publiée dans / Final version of the manuscript published in :

Carbohydrates Polymers (2017), Vol. 156, p. 152-164, DOI: 10.1016/j.carbpol.2016.09.019

Journal homepage : www.elsevier.com/locate/carbpol

A

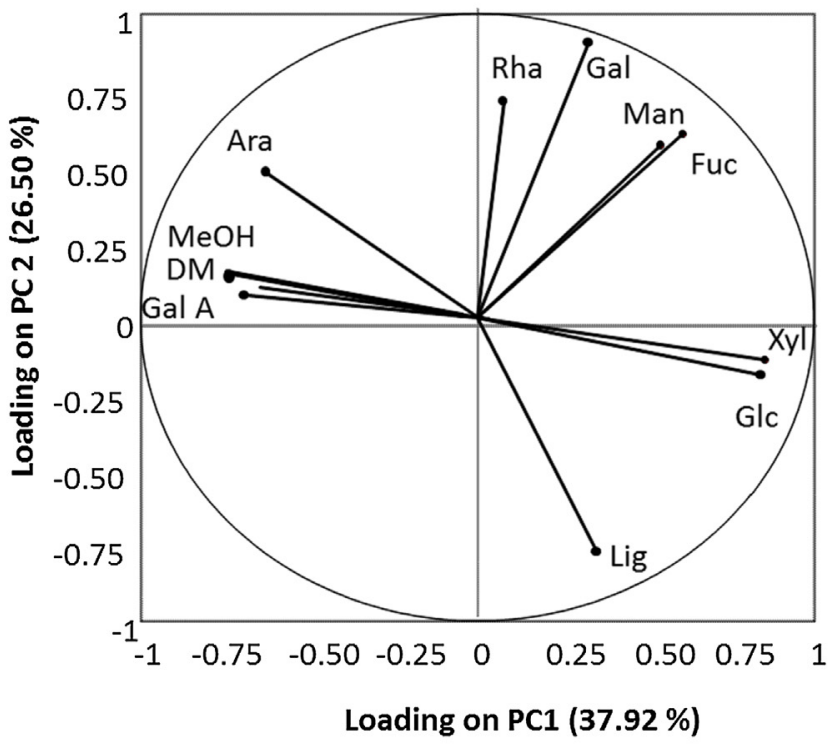

B

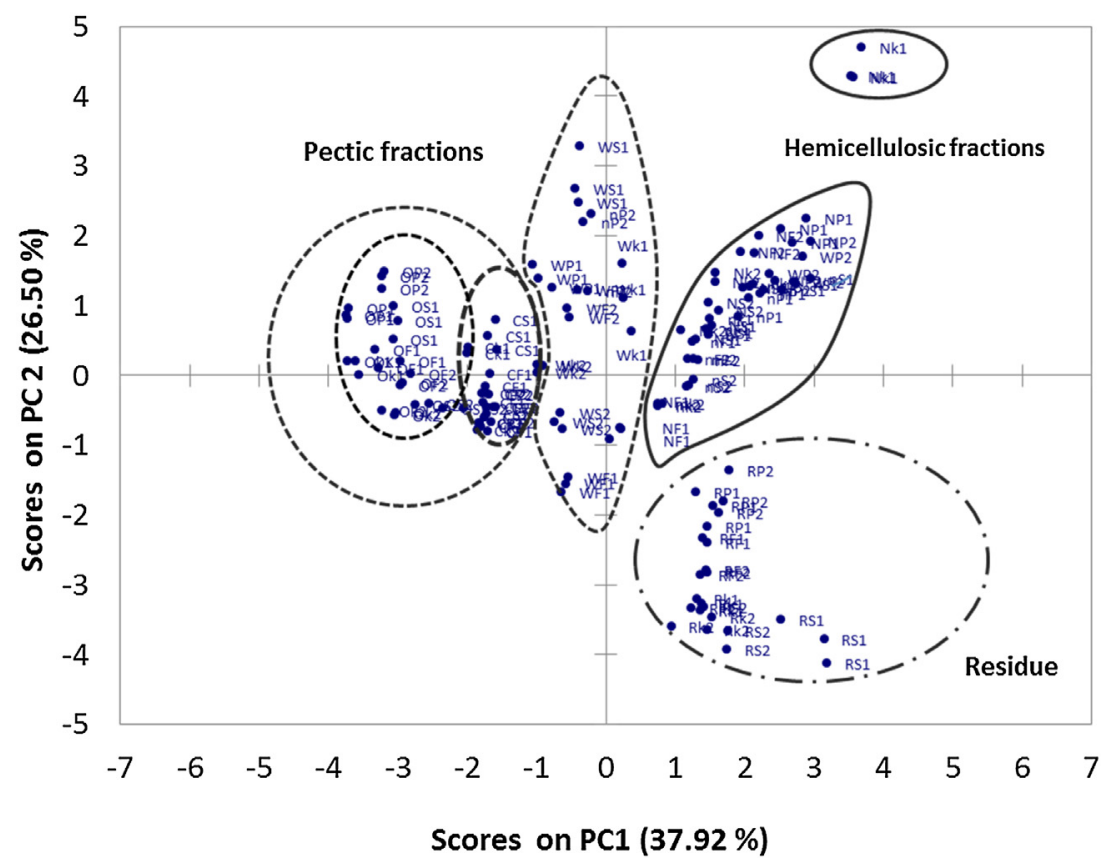

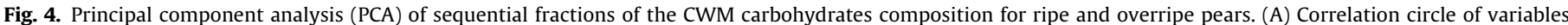
loadings on PC1 (37.92\%) and PC2 (26.50\%). (B) Sample map of scores on PC1 (37.92\%) and PC2 (26.50\%) as function of extracts, tissue types and maturity stages. Sample codifications:

Extracts-:O: Ammonium oxalate fraction, C: Dilute alkali soluble pectin (Na2CO3), n: NaOH $1 \mathrm{M}$ fraction, N: NaOH 4 M fraction, W: Water wash fraction and R: Residue. Tissue type-: F: Flesh, P: Parenchyma cells, S: Stone cells, K: Skin.

Maturity-: 1: -Ripe, 2: -Overripe.

wall arabinose and uronic acids. The same tendency is observed in the uronic acid content of the $\mathrm{Na}_{2} \mathrm{CO}_{3}$ fraction from "Yali" pears (Hiwasa et al., 2004). In apple, galactose and arabinose decrease in CDTA and $\mathrm{Na}_{2} \mathrm{CO}_{3}$ extracts during ripening (Fischer et al., 1994). There was no significant change of the DM between ripe and overripe stage except for SK which DM decreased in the overripe pears but remained high. In apple, the DM appears to be relatively stable during development and ripening (Fischer et al., 1994).

\subsubsection{Size exclusion chromatography of pectic extract}

To further explore the overripening effect on pectic polysaccharides, both ammonium and $\mathrm{Na}_{2} \mathrm{CO}_{3}$ soluble fractions were analyzed 
Version définitive du manuscrit publiée dans / Final version of the manuscript published in :

Carbohydrates Polymers (2017), Vol. 156, p. 152-164, DOI: 10.1016/j.carbpol.2016.09.019

Journal homepage : www.elsevier.com/locate/carbpol

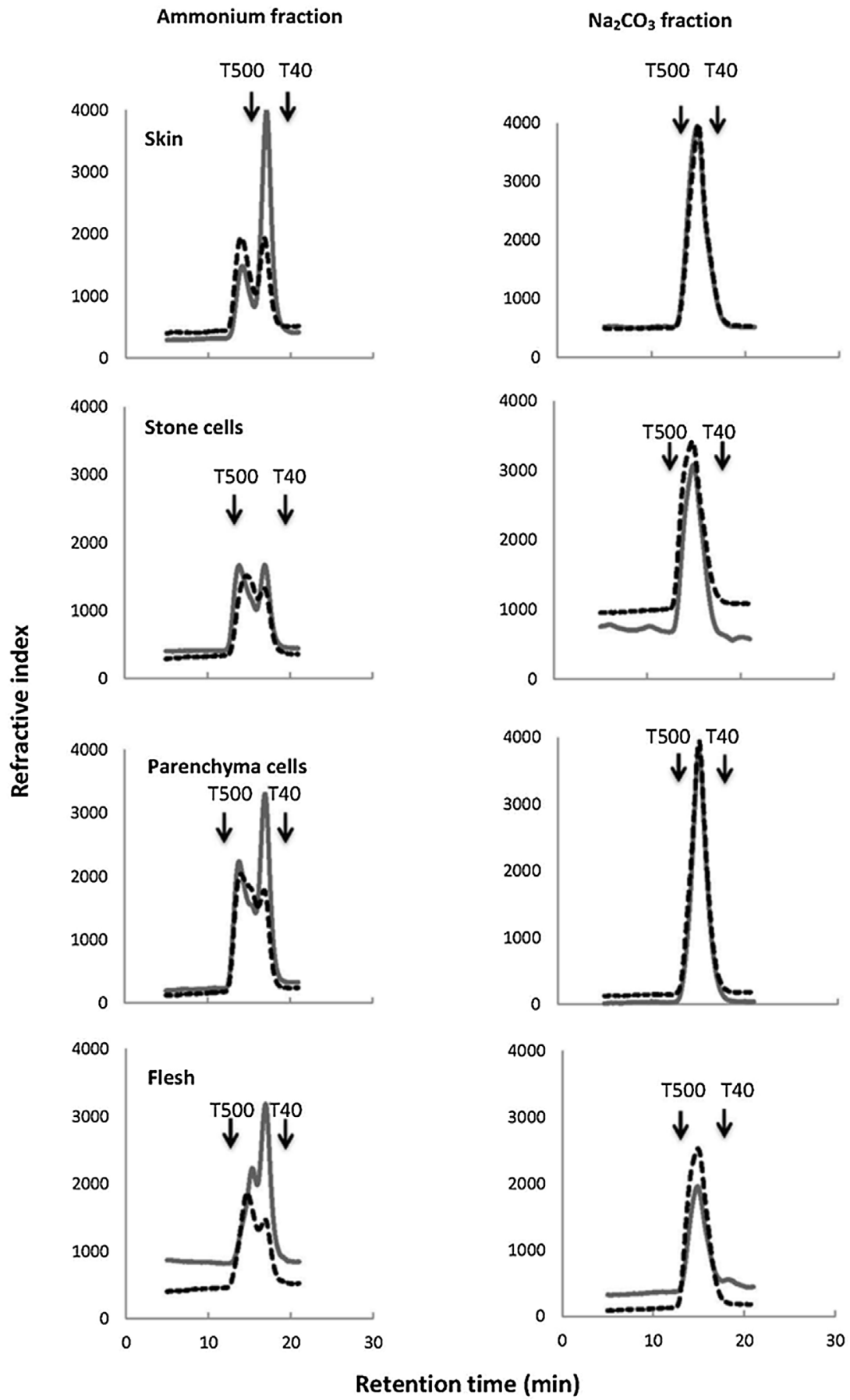

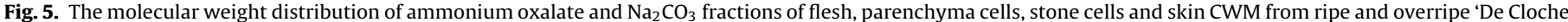
'pears by HPSEC. Arrows indicate the retention time of dextran molecular weight markers (500 and $40 \mathrm{kDa}$ ).

by HPSEC. Ammonium oxalate fractions (Fig. 5) presented two populations for FL, PC, ST and SK: one fraction of high molecular weight eluted at $14 \mathrm{~min}$ (void volume) and the second of lower molecular weight eluted at $16 \mathrm{~min}$. During ripening, the low molecular weight fraction decreased for overripe pears. This decrease might be due to depolymerisation during overripening, as pectins are converted to oligomers which are not retained during washing with ionic buffer during the isolation of cell walls. All $\mathrm{Na}_{2} \mathrm{CO}_{3}$ extracts (Fig. 5) showed a single peak without marked differences between ripe and overripe pears for all tissues. During ripening, the water soluble pectin increase with a simultaneous decrease in high molecular weight CDTA soluble pectin from "Bartlett" pears and "Red Gold" apples (Yoshioka et al., 1992). Also, in the water soluble pectin extracted from European pear cv. "La France", the proportion of the low molecular weight polysaccharides increased with ripening (Hiwasa et al., 2004). $\mathrm{Na}_{2} \mathrm{CO}_{3}$ extracts often elute as a peak of moderate molecular weight, and often show little change in molecular weight profile with ripening (Brummell, Dal Cin, Crisosto, \& Labavitch, 2004). Fischer et al. (1994) observe no decrease of the average molecular weight in apple extracts during growth and ripening. Absence of pectin depolymerisation is described during ripening of cherry (Batisse et al., 1994Batisse, Fils-Lycaon, \& Buret, 1994). Ripening only led to slight pectin depolymerisation in pears as reported e.g. in other Rosaceae such as apple (Fischer et al., 1994). 
Version définitive du manuscrit publiée dans / Final version of the manuscript published in :

Carbohydrates Polymers (2017), Vol. 156, p. 152-164, DOI: 10.1016/j.carbpol.2016.09.019

\section{Journal homepage : www.elsevier.com/locate/carbpol}

\subsubsection{Composition of hemicellulosic extracts}

Different classes of hemicellulose were extracted by progressively increasing $\mathrm{NaOH}$ concentrations ( $\mathrm{NaOH} 1 \mathrm{M}$ and $\mathrm{NaOH} 4 \mathrm{M}$ ). For FL, PC and ST NaOH $4 \mathrm{M}$ was the main extract while $\mathrm{NaOH} 1 \mathrm{M}$ extracts constituted a very minor fraction (Table 3). For SK, $\mathrm{NaOH}$ $4 \mathrm{M}$ and $\mathrm{NaOH} 1 \mathrm{M}$ yields were close. The yield of $\mathrm{NaOH} 4 \mathrm{M}$ extract decreased by about 50\% during overripening for FL and ST, while it was stable for SK and increased slightly for PC. Martin-Cabrejas et al. (1994a,b) and Yamaki et al. (1979) report also a sharp decrease in hemicellulose fractions during pear maturation. The composition of $\mathrm{NaOH} 1 \mathrm{M}$ and $4 \mathrm{M}$ extracts indicated the probable presence of linear xylans and mannans. Xylans and mannans constitute $21 \%$ and $1 \%$ respectively of the ethanol insoluble material in "Conference" pears (Jermyn \& Isherwood, 1956).

$\mathrm{NaOH} 1 \mathrm{M}$ and $\mathrm{NaOH} 4 \mathrm{M}$ fractions contained mainly xylose, glucose, galactose and arabinose. The highest xylose concentration was detected in ST, linked to deposition of xylans during secondarization of cell walls. Fucose was also present in all CWM types (about $4 \mathrm{~mol} \%$ ) and it might indicate the presence of fucogalactoxyloglucan as a minor component in pear cell walls. Mannose was especially extracted in the $\mathrm{NaOH} 4 \mathrm{M}$ fraction, indicating the presence of mannans.

The ratio Xyl/Man (Table 3) describes the contribution of xylans or mannans to the hemicellulose population. Xylose (hence xylans) was always much more abundant. Xyl/Man ratio was highest in $\mathrm{NaOH} 1 \mathrm{M}$ fractions indicating a prevalence of xylans especially for ST, FL and PC. It was lower for skin ( 8 for ripe SK and 12 for overripe SK) showing a relative higher contribution of mannans in the skin. Though xylans were still dominant, the FL, ST and PC NaOH $4 \mathrm{M}$ fractions also contained non negligible mannans. However, $\mathrm{NaOH}$ $4 \mathrm{M}$ skin extract contained less mannans than $\mathrm{NaOH} 1 \mathrm{M}$ extract. The non negligible amounts of arabinose (> $11 \mathrm{~mol} \%$ ) could point to the presence of arabinoxylans or the incidence of highly branching of rhamnogalacturonans I. The presence of high arabinoxylans content was reported in "Bartlett" pears after ripening (Raffo et al., 2011).

\subsubsection{Composition of residue}

All CWM isolated from ripe and overripe "De Cloche" pears showed very high contents of cellulose and lignin, and final residues were in all cases the main fraction, with yields generally $>65 \%$ of initial weight except for PC (Table 2). The proportion of residue increased for overripe FL and PC and for SK. It remained relatively stable for ST. In Japanese and Spanish pears, the cellulosic residue decrease with overripening (Martin-Cabrejas et al., 1994a,b; Yamaki et al., 1979). For other pears, the amounts of cellulose is unchanged (Ahmed \& Labavitch, 1980). The residue had high proportions of glucose (about $40 \mathrm{~mol} \%$ for FL, PC and ST). Xylose was also present in high amounts in ST, SK and FL (>40 mol\%), probably from highly retained xylans. Stone cells residue had the highest lignin content ( $40 \%$ of residue) followed by skin (33\% of residue). Martin-Cabrejas et al., (1994a,b) report about 52\% Klason lignin in pear residue. In parenchyma cells and flesh residues, the content of lignin varied between 15 and $20 \%$.

The composition of hemicelluloses fractions differed slightly in the xylose and glucose amounts and in some pectic monomers such as arabinose. The composition of residue fraction was relatively less modified during overripening except stone cells for which glucose and xylose decreased in the overripe pears.

\section{Conclusion}

Pear cell walls were very heterogeneous compared to other fruits due to the presence of two types of cells in the flesh: parenchyma cells and stone cells with different ultrastructures and compositions. The use of non destructive methods as infrared spectroscopy and scanning electron microscopy allowed a differentiation between different pear tissues. Chemically, the main difference was a higher pectin content (uronic acid, arabinose, rhamnose and galactose) in the parenchyma cells and a higher hemicellulose, cellulose and lignin in the stone cells. Thus, stone cells were harder and stiffer than parenchyma cells. The skin cell wall was also distinct, notably by its higher proportion of lignin and cellulose, and lower pectins. The clearest difference after overripening was found in the proportion of arabinose and in less extent galactose, which decreased in ammonium oxalate fraction of all overripe tissues, indicating the breakdown of arabinogalactan side chain presumably from rhamnogalacturonans. However, the (Arabinose + galactose) to rhamnose ratio decreased most in parenchyma cells (and whole flesh). Stone and skin were less affected by overripening due to their richness in cellulose and lignin. Therefore, for parenchyma cells (and whole flesh), the loss of arabinan/galactan side chains could modify physical properties of cell walls by increasing their pore size. Thus, the cell wall might become a much more open structure allowing enhanced accessibility of binding side for other polymers such as procyanidins, especially after overripening. (Brummell, 2006; Watrelot, Le Bourvellec, Imberty, \& Renard, 2014).

\section{Acknowledgements}

The authors thank Isabelle Bornard (INRA, Avignon) for microscopy sessions, Line Touloumet, Marielle Boge and Romain Bott (INRA, Avignon) for their technical help. We gratefully acknowledge Henk Schols and Suzanne Broxterman (Wageningen University, Netherlands). We thank also Régis Aubry (Clécy, France) for the supply of pears.

Marwa Brahem was supported by a PhD grant (RB3C-2476) from the Ministry of Higher Education and Scientific Research of Tunisia.

\section{Appendix A. Supplementary data}

Supplementary data associated with this article can be found, in the online version, at http://dx.doi.org/10.1016/j.carbpol.2016.09. 019.

\section{References}

Ahmed, A. E., \& Labavitch, J. M. (1980). Cell wall metabolism in ripening fruit I cell wall changes in ripening bartlett pears. Plant Physiology, 65(5), 1009-1013.

Almeida, D., Gomes, M., Pintado, M., 2009. Polysaccharide composition of dietary fiber and cell walls from'Rocha'pear at two ripening stages. III International Symposium on Human Health Effects of Fruits and Vegetables-FAVHEALTH 2009 (Vol. 1040, pp. 23-29): Acta Hort.

Batisse, C., Fils-Lycaon, B., \& Buret, M. (1994). Pectin changes in ripening cherry fruit. Journal of Food Science, 59(2), 389-393.

Ben-Arie, R., Kislev, N., \& Frenkel, C. (1979). Ultrastructural changes in the cell walls of ripening apple and pear fruit. Plant Physiology, 64(2), 197-202.

Bertrand, D., Courcoux, P., Autran, J. C., Meritan, R., \& Robert, P. (1990). Stepwise canonical discriminant analysis of continuous digitalized signals: Application to chromatograms of wheat proteins. Journal of Chemometrics, 4(6), 413-427.

Bindon, K. A., \& Kennedy, J. A. (2011). Ripening-Induced changes in grape skin proanthocyanidins modify their interaction with cell walls. Journal of Agricultural and Food Chemistry, 59, 2696-2707.

Bindon, K. A., Madani, S. H., Pendleton, P., Smith, P. A., \& Kennedy, J. A. (2014). Factors affecting skin tannin extractability in ripening grapes. Journal of Agricultural and Food Chemistry, 62(5), 1130-1141.

Blumenkrantz, N., \& Asboe-Hansen, G. (1973). New method for quantitative determination of uronic acids. Analytical Biochemistry, 484-489.

Box, G. E., Hunter, W. G., \& Hunter, J. S. (1978). Statistics for experimenters, an introduction to design, data analysis and model building. New York: Wiley and Sons., p. 352

Brummell, D. A., Dal Cin, V., Crisosto, C. H., \& Labavitch, J. M. (2004). Cell wall metabolism during maturation, ripening and senescence of peach fruit. Journal of Experimental Botany, 55(405), 2029-2039.

Brummell, D. A. (2006). Cell wall disassembly in ripening fruit. Functional Plant Biology, 33(2), 103-119. 


\section{Version définitive du manuscrit publiée dans / Final version of the manuscript published in : Carbohydrates Polymers (2017), Vol. 156, p. 152-164, DOI: 10.1016/j.carbpol.2016.09.019 Journal homepage : www.elsevier.com/locate/carbpol}

Cai, Y., Li, G., Nie, J., Lin, Y., Nie, F., Zhang, J., et al. (2010). Study of the structure and biosynthetic pathway of lignin in stone cells of pear. Scientia Horticulturae, 125(3), 374-379.

Choi, J.-H., Choi, J.-J., Hong, K.-H., Kim, W.-S., \& Lee, S.-H. (2007). Cultivar differences of stone cells in pear flesh and their effects on fruit quality. Horticulture Environment and Biotechnology, 48(1), 27-31.

Coimbra, M. A., Barros, A., Barros, M., Rutledge, D. N., \& Delgadillo, I. (1998). Multivariate analysis of uronic acid and neutral sugars in whole pectic samples by FT-IR spectroscopy. Carbohydrate Polymers, 37(3), 241-248.

Cordella, C. B. Y., \& Bertrand, D. (2014). SAISIR: A new general chemometric toolbox. TrAC Trends in Analytical Chemistry, 54, 75-82.

Del Río, J. C., Rencoret, J., Marques, G., Gutiérrez, A., Ibarra, D., Santos, J. I., et al. (2008). Highly acylated (Acetylated and/or p-Coumaroylated) native lignins from diverse herbaceous plants. Journal of Agricultural and Food Chemistry, 56(20), 9525-9534.

Dick, A. J., \& Labavitch, J. M. (1989). Cell wall metabolism in ripening fruit IV. characterization of the pectic polysaccharides solubilized during softening ofBartlett'Pear fruit. Plant Physiology, 89(4), 1394-1400.

Dubois, M., Gilles, K. A., Hamilton, J. K., Rebers, P., \& Smith, F. (1956). Colorimetric method for determination of sugars and related substances. Analytical Chemistry, 28(3), 350-356.

Englyst, H., Wiggins, H., \& Cummings, J. (1982). Determination of the non-starch polysaccharides in plant foods by gas-liquid chromatography of constituent sugars as alditol acetates. Analyst, 107(1272), 307-318.

Fasoli, M., Dell'Anna, R., Dal Santo, S., Balestrini, R., Sanson, A., Pezzotti, M., et al. (2016). Pectins, hemicelluloses and celluloses show specific dynamics in the internal and external surfaces of grape berry skin during ripening. Plant and Cell Physiology [pcw080].

Ferreira, D., Barros, A., Coimbra, M., \& Delgadillo, I. (2001). Use of FT-IR spectroscopy to follow the effect of processing in cell wall polysaccharide extracts of a sun-dried pear. Carbohydrate Polymers, 45(2), 175-182.

Ferreira, D., da Silva, J. A. L., Pinto, G., Santos, C., Delgadillo, I., \& Coimbra, M. A (2008). Effect of sun-drying on microstructure and texture of S. Bartolomeu pears (Pyrus communis L.). European Food Research and Technology, 226(6), 1545-1552.

Fischer, M., Arrigoni, E., \& Amadò, R. (1994). Changes in the pectic substances of apples during development and postharvest ripening. Part 2: Analysis of the pectic fractions. Carbohydrate Polymers, 25(3), 167-175.

Gille, S., \& Pauly, M. (2012). O-acetylation of plant cell wall polysaccharides. Frontiers in Plant Science, 3, 9

Guyot, S., Marnet, N., \& Drilleau, J.-F. (2001). Thiolysis-HPLC characterization of apple procyanidins covering a large range of polymerization states. Journal of Agricultural and Food Chemistry, 49(1), 14-20.

Guyot, S., Marnet, N., Le Bourvellec, C., \& Drilleau, J. (2002). Highly polymerised procyanidins in fruits and juices of perry pear (Pyrus communis) varieties. Polyphenols Communications, 2002.

Guyot, S., Marnet, N., Sanoner, P., \& Drilleau, J.-F. (2003). Variability of the polyphenolic composition of cider apple (Malus domestica) fruits and juices. Journal of Agricultural and Food Chemistry, 51(21), 6240-6247.

Heredia-Guerrero, J. A., Benítez, J. J., Domínguez, E., Bayer, I. S., Cingolani, R., Athanassioua, A., et al. (2016). Infrared spectroscopy as a tool to study plant cuticules. Spectroscopy Europe, 28(2), 10-13.

Hiwasa, K., Nakano, R., Hashimoto, A., Matsuzaki, M., Murayama, H., Inaba, A., et al. (2004). European, Chinese and Japanese pear fruits exhibit differential softening characteristics during ripening. Journal of Experimental Botany, 55(406), 2281-2290

Houben, K., Jolie, R. P., Fraeye, I., Van Loey, A. M., \& Hendrickx, M. E. (2011). Comparative study of the cell wall composition of broccoli, carrot, and tomato: Structural characterization of the extractable pectins and hemicelluloses. Carbohydrate Research, 346(9), 1105-1111.

Jermyn, M., \& Isherwood, F. (1956). Changes in the cell wall of the pear during ripening. Biochemical Journal, 64(1), 123.

Kačuráková, M., \& Wilson, R. (2001). Developments in mid-infrared FT-IR spectroscopy of selected carbohydrates. Carbohydrate Polymers, 44(4), 291-303.

Kačuráková, M., Capek, P., Sasinkova, V., Wellner, N., \& Ebringerova, A. (2000). FT-IR study of plant cell wall model compounds: Pectic polysaccharides and hemicelluloses. Carbohydrate Polymers, 43(2), 195-203.

Kyomugasho, C., Christiaens, S., Shpigelman, A., Van Loey, A. M., \& Hendrickx, M. E. (2015). FT-IR spectroscopy: A reliable method for routine analysis of the degree of methylesterification of pectin in different fruit-and vegetable-based matrices. Food Chemistry, 176, 82-90.

Le Bourvellec, C., Guyot, S., \& Renard, C. M. G. C. (2004). Non-covalent interaction between procyanidins and apple cell wall material: Part I. Effect of some environmental parameters. Biochimica Et Biophysica Acta (BBA) - General Subjects, 1672(3), 192-202

Le Bourvellec, C., Le Quere, J.-M., \& Renard, C. M. G. C. (2007). Impact of noncovalent interactions between apple condensed tannins and cell walls on their transfer from fruit to juice: Studies in model suspensions and application. Journal of Agricultural and Food Chemistry, 55(19), 7896-7904.

Le Bourvellec, C., Guyot, S., \& Renard, C. M. G. C. (2009). Interactions between apple (Malus x domestica Borkh.) polyphenols and cell walls modulate the extractability of polysaccharides. Carbohydrate Polymers, 75(2), 251-261.
Le Bourvellec, C., Bouzerzour, K., Ginies, C., Regis, S., Plé, Y., \& Renard, C. M. (2011). Phenolic and polysaccharidic composition of applesauce is close to that of apple flesh. Journal of Food Composition and Analysis, 24(4), 537-547.

Le Bourvellec, C., Gouble, B., Bureau, S., Loonis, M., Plé, Y., \& Renard, C. M. G. C. (2013). Pink discoloration of canned pears: Role of procyanidin chemical depolymerization and procyanidin/cell wall interactions. Journal of Agricultural and Food Chemistry, 61(27), 6679-6692.

Marcelin, O., Williams, P., \& Brillouet, J.-M. (1993). Isolation and characterisation of the two main cell-wall types from guava (Psidium guajava L.) pulp. Carbohydrate Research, 240, 233-243.

Martin-Cabrejas, M., Waldron, K. W., \& Selvendran, R. R. (1994). Cell wall changes in spanish pear during ripening. Journal of Plant Physiology, 144(4-5), 541-548.

Martin-Cabrejas, M. A., Waldron, K. W., Selvendran, R. R., Parker, M. L., \& Moates, G. K. (1994). Ripening related changes in the cell walls of Spanish pear (Pyrus communis. Physiologia Plantarum, 91(4), 671-679.

Murayama, H., Katsumata, T., Endou, H., Fukushima, T., \& Sakurai, N. (2006). Effect of storage period on the molecular-mass distribution profile of pectic and hemicellulosic polysaccharides in pears. Postharvest Biology and Technology, 40(2), 141-148.

Pawar, P. M. A., Derba-Maceluch, M., Chong, S. L., Gómez, L. D., Miedes, E., Banasiak, A., et al. (2016). Expression of fungal acetyl xylan esterase in Arabidopsis thaliana improves saccharification of stem lignocellulose. Plant Biotechnology Journal, 14(1), 387-397.

Raffo, M. D., Ponce, N. M. A., Sozzi, G. O., Vicente, A. R., \& Stortz, C. A. (2011). Compositional changes in 'Bartlett' pear (Pyrus communis L.) cell wall polysaccharides As affected by sunlight conditions. Journal of Agricultural and Food Chemistry, 59(22), 12155-12162.

Renard, C. M. G. C., \& Ginies, C. (2009). Comparison of the cell wall composition for flesh and skin from five different plums. Food Chemistry, 114(3), 1042-1049.

Renard, C. M. G. C., Voragen, A. G. J., Thibault, J. F., \& Pilnik, W. (1991). Studies on apple protopectin V: Structural studies on enzymatically extracted pectins. Carbohydrate Polymers, 16(2), 137-154.

Renard, C. M. G. C., Baron, A., Guyot, S., \& Drilleau, J.-F. (2001). Interactions between apple cell walls and native apple polyphenols: Quantification and some consequences. International Journal of Biological Macromolecules, 29(2), $115-125$.

Renard, C. M. G. C. (2005a). Effects of conventional boiling on the polyphenols and cell walls of pears. Journal of the Science of Food and Agriculture, 85(2), 310-318.

Renard, C. M. G. C. (2005b). Variability in cell wall preparations: Quantification and comparison of common methods. Carbohydrate Polymers, 60(4), 515-522.

Saeman, J. F., Moore, W. E., Mitchell, R. L., \& Millett, M. A. (1954). Techniques for the determination of pulp constituents by quantitiative paper chromatography. Tappi Journal, 37(8), 336-343.

Schols, H. A., \& Voragen, A. G. (1994). Occurrence of pectic hairy regions in various plant cell wall materials and their degradability by rhamnogalacturonase. Carbohydrate Research, 256(1), 83-95.

Sirisomboon, P., Tanaka, M., Fujita, S., \& Kojima, T. (2000). Relationship between the texture and pectin constituents of Japanese pear. Journal of Texture Studies 31(6), 679-690.

Smith, P., McRae, J., \& Bindon, K. (2015). Impact of winemaking practices on the concentration and composition of tannins in red wine. Australian Journal of Grape and Wine Research, 21(S1), 601-614.

Syros, T., Yupsanis, T., Zafiriadis, H., \& Economou, A. (2004). Activity and isoforms of peroxidases, lignin and anatomy, during adventitious rooting in cuttings of Ebenus cretica L. Journal of Plant Physiology, 161(1), 69-77.

Szymanska-Chargot, M., Chylinska, M., Kruk, B., \& Zdunek, A. (2015). Combining FT-IR spectroscopy and multivariate analysis for qualitative and quantitative analysis of the cell wall composition changes during apples development. Carbohydrate Polymers, 115, 93-103.

Tao, S., Khanizadeh, S., Zhang, H., \& Zhang, S. (2009). Anatomy, ultrastructure and lignin distribution of stone cells in two Pyrus species. Plant Science, 176(3), 413-419.

Vance, C., Kirk, T., \& Sherwood, R. (1980). Lignification as a mechanism of disease resistance. Annual Review of Phytopathology, 18(1), 259-288.

Watrelot, A. A., Le Bourvellec, C., Imberty, A., \& Renard, C. M. G. C. (2014). Neutral sugar side chains of pectins limit interactions with procyanidins. Carbohydrate Polymers, 99, 527-536.

Wong, D. (2008). Enzymatic deconstruction of backbone structures of the ramified regions in pectins. The Protein Journal, 27(1), 30-42.

Yamaki, S., Machida, Y., \& Kakiuchi, N. (1979). Changes in cell wall polysaccharides and monosaccharides during development and ripening of Japanese pear fruit. Plant and Cell Physiology, 20(2), 311-321.

Yan, C., Yin, M., Zhang, N., Jin, Q., Fang, Z., Lin, Y., et al. (2014). Stone cell distribution and lignin structure in various pear varieties. Scientia Horticulturae, 174, 142-150.

Yoshioka, H., Aoba, K., \& Kashimura, Y. (1992). Molecular weight and degree of methoxylation in cell wall polyuronide during softening in pear and apple fruit. Journal of the American Society for Horticultural Science, 117(4), 600-606.

Zykwinska, A., Rondeau-Mouro, C., Garnier, C., Thibault, J.-F., \& Ralet, M.-C. (2006). Alkaline extractability of pectic arabinan and galactan and their mobility in sugar beet and potato cell walls. Carbohydrate Polymers, 65(4), 510-520. 